Article

\title{
Analysis of the Temporal Changes of Inland Ramsar Sites in Turkey Using Google Earth Engine
}

\author{
Adalet Dervisoglu
}

check for updates

Citation: Dervisoglu, A. Analysis of the Temporal Changes of Inland Ramsar Sites in Turkey Using Google Earth Engine. ISPRS Int. J. Geo-Inf. 2021, 10, 521. https://doi.org/ $10.3390 /$ ijgi10080521

Academic Editor: Wolfgang Kainz

Received: 4 June 2021

Accepted: 28 July 2021

Published: 31 July 2021

Publisher's Note: MDPI stays neutral with regard to jurisdictional claims in published maps and institutional affiliations.

Copyright: (C) 2021 by the author. Licensee MDPI, Basel, Switzerland. This article is an open access article distributed under the terms and conditions of the Creative Commons Attribution (CC BY) license (https:// creativecommons.org/licenses/by/ $4.0 /)$.
Geomatics Engineering Department, Civil Engineering Faculty, Istanbul Technical University, 34467 Istanbul, Turkey; adervisoglu@itu.edu.tr

\begin{abstract}
Ramsar Convention (RC) is the first of modern intergovernmental agreement on the conscious use and conservation of natural resources. It provides a platform for contracting parties working together to develop the best available data, advice, and policy recommendations to increase awareness of the benefits of wetlands in nature and society. Turkey became a party of the RC in 1994, and in the years 1994 to 2013, 14 wetlands that reached the Ramsar criteria were recognized as Ramsar sites (RS). With this study, all inland RS in Turkey from 1985 to 2020 were examined, and changes in the water surface areas were evaluated on the GEE cloud computing platform using Landsat satellite images and the NDWI index. The closest meteorological station data to each RS were evaluated and associated with the surface area changes. The reasons for the changes in these areas, besides the meteorological effects, have been scrutinized using management plans and publications. As a result, inland wetlands decreased at different rates from 1985 to 2020 , with a total loss of $31.38 \%$ and $21,571.0$ ha for the spring months. Since the designation dates of RS, the total amount of water surface area reduction was $27.35 \%$, constituting $17,758.90$ ha.
\end{abstract}

Keywords: Ramsar sites; wetland; GEE; remote sensing; NDWI; Landsat; Turkey; Meke Maar; Nemrut Caldera

\section{Introduction}

Wetlands are essential components of the environment in terms of preserving the natural equilibrium and biodiversity with their variety of functions, including drinking water provision, sediment and nutrient storage, and flood and climate change control, as well as being used for natural remediation, fishing, feeding groundwater, and cultural purposes. They are also the most critical global genetic reserves, inhabiting $40 \%$ of all species and 12\% of animal species [1]. Throughout all these roles and drives, wetlands contribute remarkably to regional and national economies. Scientific studies have indicated that $64 \%$ of the world's wetlands have disappeared since the 1900 s. The leading causes for the degradation and loss of wetlands are changes in land-use; significantly increased agriculture; water diversion through dams, dikes, and canalization, particularly in river valleys and coastal areas; air and water pollution; and disposal of excess nutrients [2]. Efforts have been made to improve and protect the remaining wetlands, and strategies have been developed to appreciate the importance of wetlands. The Ramsar Convention is the first of modern intergovernmental agreement on the conscious use and conservation of natural resources. It was developed in the 1960s as a response to the increasing concerns on the conversion and destruction of wetlands, as well as for the impacts on people and biodiversity, especially on water birds [3]. It was accepted in 1971, and put into force in 1975. The United Nations Educational, Scientific, and Cultural Organization (UNESCO) acts as the legal depositary of the convention, which provides the single most global framework for intergovernmental cooperation on wetland issues and a platform of 171 contracting parties working together to develop the best available data, advice, and policy recommendations in order to increase the awareness of the benefits of wetlands in nature and society. The parties of the convention have committed to preserving the 
ecological character of more than 2300 wetlands of international importance, covering approximately 250 million hectares, which covers $13-18 \%$ of the global wetlands [4].

Under the text of the Ramsar Convention, wetlands are defined as "areas of marsh, fen, peatland or water, whether natural or artificial, permanent or temporary, with water that is static or flowing, fresh, brackish or salt, including areas of marine water the depth of which at low tide does not exceed six meters". The convention has accepted a Ramsar Classification of wetland type, which includes 42 types, grouped into the following three categories: marine and coastal wetlands $(\mathrm{M} / \mathrm{C})$, inland wetlands (I), and human-made wetlands. Each Ramsar site meets at least one of nine criteria-related to wetland types; ecological communities; and support for water birds, fish, and other taxa-that signify international importance. These criteria are given in Table 1 [5].

Table 1. Ramsar Criteria.

\begin{tabular}{|c|c|}
\hline Criteria. & Explanation \\
\hline 1 & $\begin{array}{l}\text { A wetland should be considered internationally important if it contains a representative, rare, or unique example of } \\
\text { a natural or near-natural wetland type found within the appropriate biogeographic region. }\end{array}$ \\
\hline 2 & $\begin{array}{c}\text { A wetland should be considered internationally important if it supports vulnerable, endangered, or critically } \\
\text { endangered species or threatened ecological communities. }\end{array}$ \\
\hline 3 & $\begin{array}{c}\text { A wetland should be considered internationally important if it supports populations of plant and/or animal species } \\
\text { important for maintaining the biological diversity of a particular biogeographic region. }\end{array}$ \\
\hline 4 & $\begin{array}{l}\text { A wetland should be considered internationally important if it supports plant and/or animal species at a critical } \\
\text { stage in their life cycles, or provides refuge during adverse conditions. Specific criteria are based on water birds. }\end{array}$ \\
\hline 5 & A wetland should be considered internationally important if it regularly supports 20,000 or more water birds. \\
\hline 6 & $\begin{array}{l}\text { A wetland should be considered internationally important if it regularly supports } 1 \% \text { of the individuals in a } \\
\text { population of one species or subspecies of water bird. }\end{array}$ \\
\hline 7 & $\begin{array}{l}\text { A wetland should be considered internationally important if it supports a significant proportion of indigenous fish } \\
\text { subspecies, species, or families; life-history stages; species interactions; and/or populations that are representative } \\
\text { of wetland benefits and/or values, and thereby contributes to global biological diversity. }\end{array}$ \\
\hline 8 & $\begin{array}{l}\text { A wetland should be considered internationally important if it is an important source of food for fish, spawning } \\
\text { grounds, nurseries, and/or migration paths on which fish stocks, either within the wetland or elsewhere, depend. }\end{array}$ \\
\hline 9 & $\begin{array}{l}\text { A wetland should be considered internationally important if it regularly supports } 1 \% \text { of the individuals in a } \\
\text { population of one species or subspecies of wetland-dependent nonavian animal species. }\end{array}$ \\
\hline
\end{tabular}

Turkey's natural wetland area covers almost $2.3 \%$ of the country's surface area, with 17,269 natural wetlands managed by the General Directorate of Nature Conservation and National Parks (GDNCNP) under the Ministry of Agriculture and Forestry (MoAF). Nine hundred twenty-one of these wetlands have a size greater than 8 ha, constituting $99.48 \%$ of the overall wetland areas [6]. Turkey become a party of the Ramsar Convention in 1994, and 14 wetlands have been recognized as Ramsar sites in the years 1994 to 2013. Turkey implemented the Wetlands Protection Regulation in 2002 to fulfill the obligations. The Ramsar sites of Turkey are shown in Figure 1 and are listed in Table 2 with the site numbers, protection areas, wetland types, coordinates, designation dates, and the criteria it meets $[5,7]$.

In Turkey, almost half of the wetlands have lost their ecological and economic characteristics as a result of drying, filling, and interference in water systems in the last 40 years [8]. The most significant cause of this loss was the deliberate drying activities in the 1950s in order to combat the malaria disease. The main factors threatening wetlands in Turkey nowadays are unplanned water infrastructure projects like dams built on rivers feeding wetlands, as well as interbasin water transfers, excessive water use in agriculture, pollution, illegal hunting and fishing, other large-scale investments such as highways and mines, and management problems [9]. The factors that threaten the well-being of Turkey's Ramsar sites compiled from the existing management plans and reports are listed in Table 3. 


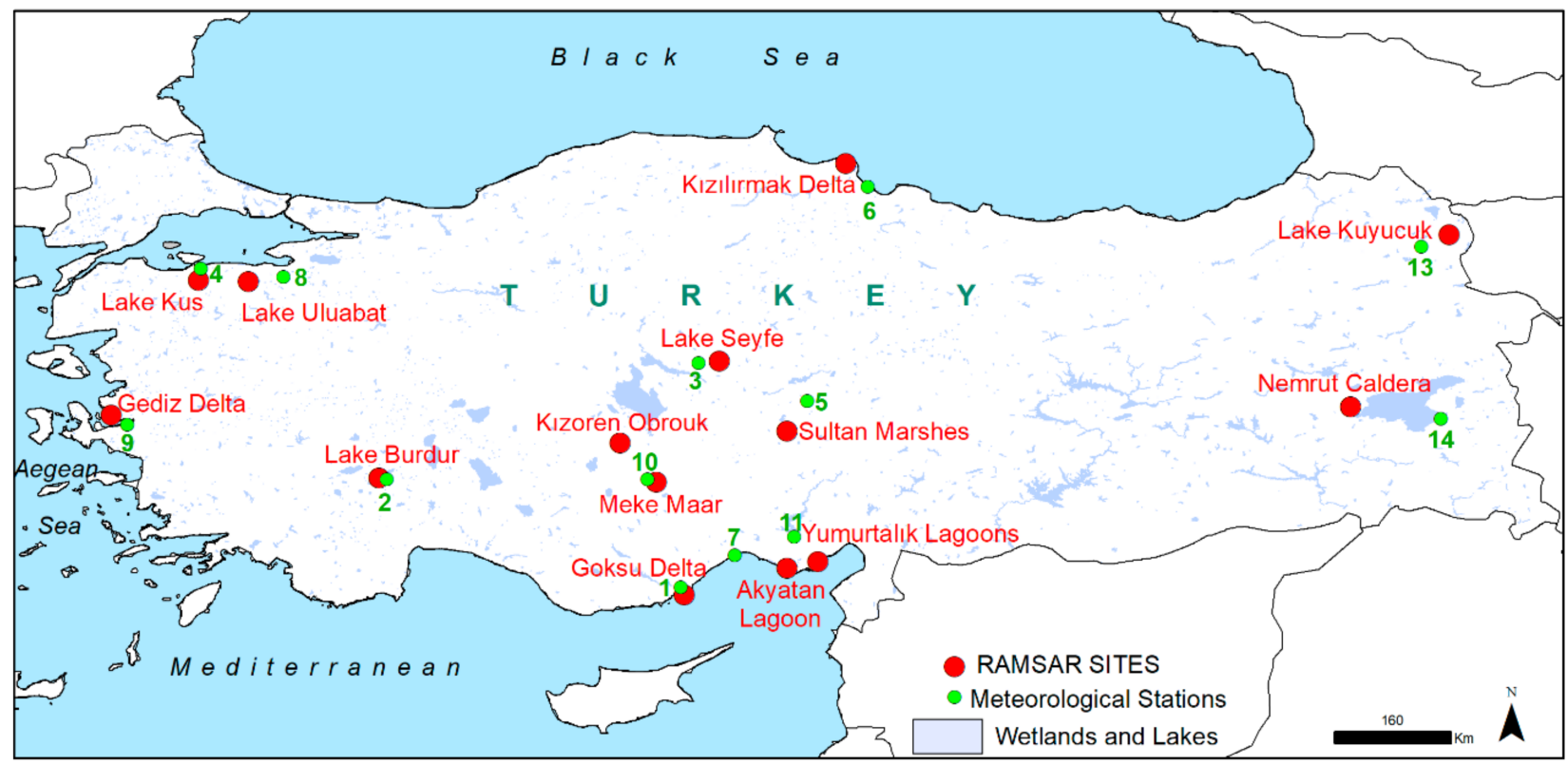

Figure 1. Turkey's Ramsar sites and nearby meteorological stations.

Table 2. Ramsar sites of Turkey

\begin{tabular}{|c|c|c|c|c|c|c|}
\hline Ramsar Site & $\begin{array}{c}\text { Ramsar } \\
\#\end{array}$ & $\begin{array}{l}\text { Wetland } \\
\text { Type * }\end{array}$ & $\begin{array}{l}\text { Ramsar } \\
\text { Criteria }\end{array}$ & Coordinates & $\begin{array}{c}\text { Protection Area } \\
\text { (ha) }\end{array}$ & $\begin{array}{c}\text { Designation } \\
\text { Date }\end{array}$ \\
\hline Goksu Delta & 657 & $\mathrm{M} / \mathrm{C}$ & $2,3,4$ & $\begin{array}{l}36^{\circ} 17^{\prime} \mathrm{N} \\
33^{\circ} 59^{\prime} \mathrm{E} \\
37^{\circ} 44^{\prime} \mathrm{N}\end{array}$ & 15,000 & 1994-07-13 \\
\hline Lake Burdur & 658 & I & $2,3,4,5,6$ & $\begin{array}{l}30^{\circ} 12^{\prime} \mathrm{E} \\
39^{\circ} 11^{\prime} \mathrm{N}\end{array}$ & 24,800 & 1994-07-13 \\
\hline Lake Seyfe & 659 & I & $2,4,5$ & $\begin{array}{l}34^{\circ} 25^{\prime} \mathrm{E} \\
40^{\circ} 11^{\prime} \mathrm{N}\end{array}$ & 10,700 & 1994-07-13 \\
\hline Lake Kus (Manyas) & 660 & I & $2,3,4,5,8$ & $\begin{array}{l}27^{\circ} 58^{\prime} \mathrm{E} \\
38^{\circ} 19^{\prime} \mathrm{N}\end{array}$ & 20,400 & 1994-07-13 \\
\hline Sultan Marshes & 661 & I & $2,3,4,5,6$ & $\begin{array}{l}35^{\circ} 15^{\prime} \mathrm{E} \\
41^{\circ} 38^{\prime} \mathrm{N}\end{array}$ & 17,200 & 1994-07-13 \\
\hline Kızılırmak Delta & 942 & $\mathrm{M} / \mathrm{C}$ & $1,2,3,5,6,7,8$ & $\begin{array}{l}35^{\circ} 59^{\prime} \mathrm{E} \\
36^{\circ} 37^{\prime} \mathrm{N}\end{array}$ & 21,700 & 1998-04-15 \\
\hline Akyatan Lagoon & 943 & $\mathrm{M} / \mathrm{C}$ & $1,2,3,4.5,6,8$ & $\begin{array}{l}35^{\circ} 15^{\prime} \mathrm{E} \\
40^{\circ} 10^{\prime} \mathrm{N}\end{array}$ & 14,700 & 1998-04-16 \\
\hline Lake Uluabat & 944 & I & $2,4,5,8$ & $\begin{array}{l}28^{\circ} 35^{\prime} \mathrm{E} \\
38^{\circ} 31^{\prime} \mathrm{N}\end{array}$ & 19,900 & 1998-06-12 \\
\hline Gediz Delta & 945 & $\mathrm{M} / \mathrm{C}$ & $2,3,4,5$ & $\begin{array}{l}26^{\circ} 53^{\prime} \mathrm{E} \\
37^{\circ} 41^{\prime} \mathrm{N}\end{array}$ & 14,900 & 1998-04-15 \\
\hline Meke Maar & 1618 & I & $1,2,3$ & $\begin{array}{l}33^{\circ} 38^{\prime} \mathrm{E} \\
36^{\circ} 42^{\prime} \mathrm{N}\end{array}$ & 202 & $2005-07-21$ \\
\hline Yumurtalık Lagoons & 1619 & $\mathrm{M} / \mathrm{C}$ & $1,2,3,4,5,6,8$ & $\begin{array}{l}35^{\circ} 38^{\prime} \mathrm{E} \\
38^{\circ} 10^{\prime} \mathrm{N}\end{array}$ & 19,853 & $2005-07-21$ \\
\hline Kizoren Obrouk & 1620 & I & 1,2 & $\begin{array}{l}33^{\circ} 11^{\prime} \mathrm{E} \\
40^{\circ} 45^{\prime} \mathrm{N}\end{array}$ & 127 & 2006-05-02 \\
\hline Lake Kuyucuk & 1890 & I & $1,2,3,4,5,6$ & $\begin{array}{l}43^{\circ} 27^{\prime} \mathrm{E} \\
38^{\circ} 37^{\prime} \mathrm{N}\end{array}$ & 416 & 2009-08-28 \\
\hline Nemrut Caldera & 2145 & I & 1 & $42^{\circ} 14^{\prime} \mathrm{E}$ & 2145 & 2013-04-17 \\
\hline
\end{tabular}


Table 3. The main factors affecting the Ramsar sites of Turkey [8,10-22].

\begin{tabular}{|c|c|}
\hline $\begin{array}{c}\text { Threats } \\
\#\end{array}$ & Threats of Turkey's Ramsar Sites \\
\hline 1 & Overuse and/or unplanned use of water resources for feeding the wetland \\
\hline 2 & Excessive use of groundwater for irrigation and/or domestic purposes \\
\hline 3 & Building dams on the freshwater sources feeding the wetland \\
\hline 4 & Water infrastructure projects affecting the wetland directly/indirectly \\
\hline 5 & Unsustainable irrigation and drainage projects \\
\hline 6 & Interventions to the water level by the official institutions \\
\hline 7 & Discharge of domestic/urban/industrial zone/factories' wastewater to the site without treatment \\
\hline 8 & Pesticides pollution \\
\hline 9 & Industrial pollution \\
\hline 10 & Uncontrolled/illegal construction and expansion activities \\
\hline 11 & Unplanned tourism/uncontrolled use of the recreational areas \\
\hline 12 & Shallowing of lakes as a result of alluvium being carried to lakes through drainage channels \\
\hline 13 & Coastal erosion \\
\hline 14 & Wind erosion \\
\hline 15 & Reed field fires to create agricultural land and excessive reed cutting \\
\hline 16 & Unplanned and uncontrolled grazing \\
\hline 17 & Sand removal from the area \\
\hline 18 & Illegal hunting \\
\hline 19 & Illegal/over-fishing and introducing alien fish species \\
\hline 20 & Solid waste accumulation on the shores \\
\hline 21 & Salinization of freshwater ecosystems and agricultural soils \\
\hline 22 & Changes in the salinity of the area with freshwater carried by the drainage channels \\
\hline 23 & Destruction of dunes and natural habitats to gain farmland \\
\hline 24 & Superstructure projects (e.g., highway and power plants) \\
\hline
\end{tabular}

Wetland Management Plans (MP) are prepared under the coordination of the GDNCNP so as to protect wetlands, identify the problems they face, develop solutions, and ensure rational use by protecting ecological functioning and biological diversity. Wetland management plans contain all technical, administrative, and hardware structures necessary to manage the areas.

Twelve of the Ramsar sites in Turkey have management plans, and the implementation and updating times of these management plans are given in Table 3, together with the different protection statuses of these sites. Factors threatening the Ramsar sites in Turkey are given in Table 4, with the items of the threats taken from Table 3 for each Ramsar Site.

It is critical to acquire correct information in order to identify wetlands of various scales (global, regional, or national), monitor them, and formulate accurate management plans. Inventory, assessment, and monitoring are vital components of effective wetland management, and provide essential data and information to support management decisions [9]. It is confirmed by many studies that remote sensing (RS) technology and data are significant and essential for determining, analyzing, and monitoring the change in wetlands through time. Since the first Earth-observing satellite (Landsat1) launched in 1972 [23], optical sensors have proved their potential to monitor large-scale land use/land-cover (LULC) change on the Earth's surface. Satellite sensors of varying spatial, temporal, and spectral resolutions have been used to extract and analyze information regarding surface water from past to present. Landsat satellites (MSS, TM, ETM +, and OLI) that continuously provide medium resolution images are among the most widely used optical sensors in environmental research in the last five decades. The use of Landsat satellite images has an important place in numerous studies where the water surface areas of wetlands are extracted or the temporal changes are determined [24-43]. 
Table 4. Implementation years, other protection status, and threats of Ramsar Sites.

\begin{tabular}{|c|c|c|c|}
\hline Ramsar Site & $\begin{array}{l}\text { Implementation } \\
\text { Year of the MP * }\end{array}$ & Other Protection Status & $\begin{array}{c}\text { \# Threats } \\
\text { (Refer to Table 3) }\end{array}$ \\
\hline Goksu Delta & $1999 / \mathrm{RP}^{*}: 2008$ & $\begin{array}{c}\text { Special Nature Conservation (1990) Area(1990) } \\
\text { Wildlife Conservation Area (1990) } \\
\text { 1st Degree Natural/Historic Site(1996) }\end{array}$ & $4,7,8,10,12,13,15,18$ \\
\hline Lake Burdur & 2008/RP:2018 & Wildlife Conservation Area (1993) & 3,7 \\
\hline Lake Seyfe & $\begin{array}{c}2011 \\
R P: 2016\end{array}$ & $\begin{array}{c}\text { 1st Degree Natural/Historic Site (1989) } \\
\text { Nature Conservation Area (1990) }\end{array}$ & 2,4 \\
\hline Lake Kus (Manyas) & $\begin{array}{c}2003 \\
R P: 2018\end{array}$ & $\begin{array}{c}\text { National Park (1959) } \\
\text { Wildlife Conservation Area (1996) } \\
\text { 1st Degree Natural/Historic Site(1981) }\end{array}$ & $6,7,15,19$ \\
\hline Sultan Marshes & 2008 & $\begin{array}{c}\text { Wildlife Conservation Area (1971 and 1984) } \\
\text { Nature Conservation Area (1988) } \\
\text { 1st Degree Natural/Historic Site (1993) } \\
\text { National Park (2006) }\end{array}$ & $1,4,7,10,14,15,16$ \\
\hline Kizilırmak Delta & $\begin{array}{c}2008 \\
R P: 2016\end{array}$ & $\begin{array}{l}\text { Wildlife Conservation Area (1979) } \\
\text { 1st Degree Natural/ Historic Site (1994) }\end{array}$ & $4,5,7,10,18$ \\
\hline Akyatan Lagoon & $\begin{array}{c}2011 \\
R P: 2018\end{array}$ & $\begin{array}{c}\text { Wildlife Protection and Reproduction Area(1987) } \\
\text { 1st Degree Natural/Historic Site (1997) } \\
\text { Wildlife Con. and Development Area (2005) }\end{array}$ & $7,19,20,22,23$ \\
\hline Lake Uluabat & 2003/ RP:2015 & Living Lakes (2001) & $4,6,9,11,18,19,24$ \\
\hline Gediz Delta & $\begin{array}{c}2007 \\
R P: 2018\end{array}$ & $\begin{array}{l}\text { Wildlife Conservation Area (1982-2007) } \\
\text { 1st Degree Natural/Historic Site (1999) }\end{array}$ & $7,9,10,18,20,21$ \\
\hline Meke Maar & under preparation & $\begin{array}{l}\text { 1st Degree Natural/Historic Site (1989) } \\
\text { Nature Monument Status }\end{array}$ & 2,14 \\
\hline Yumurtalık Lagoons & 2008 & $\begin{array}{l}\text { 1st Degree Natural/Historic Site (1993) } \\
\text { Nature Conservation Area (1994) }\end{array}$ & $1,3,8,24,17,18$ \\
\hline Kizoren Obrouk & under preparation & - & 1,2 \\
\hline Lake Kuyucuk & 2011 & $\begin{array}{l}\text { Wildlife Conservation and Development } \\
\text { Area(2005) }\end{array}$ & $1,2,3,8,16$ \\
\hline Nemrut Caldera & 2018 & $\begin{array}{c}\text { National Park (1988) } \\
\text { 1st Degree Natural/Historic Site (2002) } \\
\text { Nature Monument Status (2003) }\end{array}$ & 11 \\
\hline
\end{tabular}

$\mathrm{MP}^{*}=$ management plan; $\mathrm{RP}^{*}=$ revised plan.

The ability of cloud computing programs has been significantly improved in recent years, and they have shown great application potential in large-scale land cover mapping [44]. Cloud computing platforms such as Google Earth Engine (GEE) provide the infrastructure to access and process large amounts of regularly updated Earth Observation data rapidly in a systematic and reproducible manner [45]. The bulk of the collection comprises RS imagery, including Landsat archive and Sentinel 1 and 2 data. GEE facilitates the use of all images archived on the platform for global, national, and regional land cover mapping and land cover change monitoring. There are studies in which the water surface areas from a regional to global scale are extracted in the GEE cloud platform. In 2016, a dataset of water body changes based on the GEE platform for global large-scale, long series was published by Pekel [46]. They used 3 million Landsat images and quantified the changes on the global surface water over the past 32 years at a $30 \mathrm{~m}$ resolution. All of the available Landsat images (7534 scenes) were used for the Hetao Plain in China for determining the long-term changes of the surface water area. Normalized Difference Water Index (NDWI) and Normalized Vegetation Index (NDVI) were applied to map the open-surface water from 1989 to 2019 in the GEE [47]. In the study conducted at the Tarim River Basin of China, 56284 Landsat scenes were used to determine the available surface area and generate a $30 \mathrm{~m}$ annual water frequency map from 1992 to 2019 [48]. Moreover, the maximal and minimal water extent in 1990, 2000, 2010, and 2017 in the Middle Yangtze River Basin in China were calculated on the GEE platform by processing 2343 scenes of Landsat images [49]. Additionally, 75593 scenes of Landsat images were processed to 
investigate the long-term changes of open-surface water bodies in the Yangtze River Basin in China from 1984 to 2018 [50].

Studies showing temporal changes in the Ramsar Sites of Turkey are quite limited [51-70], and a study has not yet been conducted at a national scale. With this study, all of the Ramsar sites of Turkey were given with their various features, the Inland Ramsar sites from 1985 to 2020 were examined, and the results were compared. The study aims to determine the change in the Ramsar sites over the past 35 years, as well as the effects of being designated a Ramsar site by detecting the changes since the date that they were designated as a Ramsar site. Therefore, 1985 and the designation years were considered as the reference dates. The change in water surface areas from 1985 to 2020 was evaluated using a GEE cloud computing platform, considering the most available water supply in spring months (March, April, and May) and the least available in the autumn period (September and October). The nearby meteorological station data (temperature, precipitation, and evaporation) for each Ramsar site were evaluated and associated with the water surface area changes. The reasons for areal changes, besides the meteorological effects, were scrutinized by using the available management plans and publications.

\section{Materials and Methods}

\subsection{Materials}

This study was carried out on the GEE cloud platform. Landsat 5 TM and Landsat 8 OLI satellite images were used, and the water surface areas between 1985 and 2020 were determined for the spring and autumn periods each year for the inland Ramsar sites. In Turkey, it was observed that wetlands had the highest surface area in the spring period and the lowest in autumn. Therefore, images from March, April, and May were used for representing the water-rich period, whereas images from September and October were used to represent the water-poor period. Seasonal composite images were produced, and water surface areas were extracted using these images. The characteristics and number of images used are given in Table 5.

Table 5. Information on satellite imageries used [71,72].

\begin{tabular}{|c|c|c|c|c|c|}
\hline Satellite & $\begin{array}{c}\text { Spectral } \\
\text { Resolution } \\
(\mu \mathrm{m})\end{array}$ & $\begin{array}{c}\text { Spatial } \\
\text { Resolution } \\
\text { (m) }\end{array}$ & $\begin{array}{c}\text { Radiometric } \\
\text { Resolution } \\
\text { (bit) }\end{array}$ & $\begin{array}{l}\text { Temporal } \\
\text { Resolution } \\
\text { (day) }\end{array}$ & $\begin{array}{l}\text { Number of } \\
\text { Images Used }\end{array}$ \\
\hline $\begin{array}{c}\text { Landsat } 5 \text { TM } \\
\text { (1985-2011) }\end{array}$ & $\begin{array}{c}7 \text { Bands } \\
(0.45-2.35)\end{array}$ & $\begin{array}{c}\text { B1, B2, B3, B4, B5, } \\
\text { B5, B7:30m, } \\
\text { B6:120m }\end{array}$ & 8 & 16 & 1474 \\
\hline $\begin{array}{l}\text { Landsat } 8 \text { OLI } \\
(2013-2020)\end{array}$ & $\begin{array}{c}9 \text { Bands } \\
(0.43-2.51)\end{array}$ & $\begin{array}{c}\text { B1, B2, B3, B4, B5, } \\
\text { B6, B7, B9:30m } \\
\text { B8:15m, B10, } \\
\text { B11:30m }\end{array}$ & 16 & 16 & 505 \\
\hline
\end{tabular}

The closest meteorological stations to the Ramsar sites are numbered and given in Figure 1. Precipitation, evaporation, and temperature parameters for 1985-2020 were obtained from the Turkish State Meteorological Service. Meteorological stations' annual average temperature values are given in Figure 2 with their meteorological station numbers' associated Ramsar sites. 


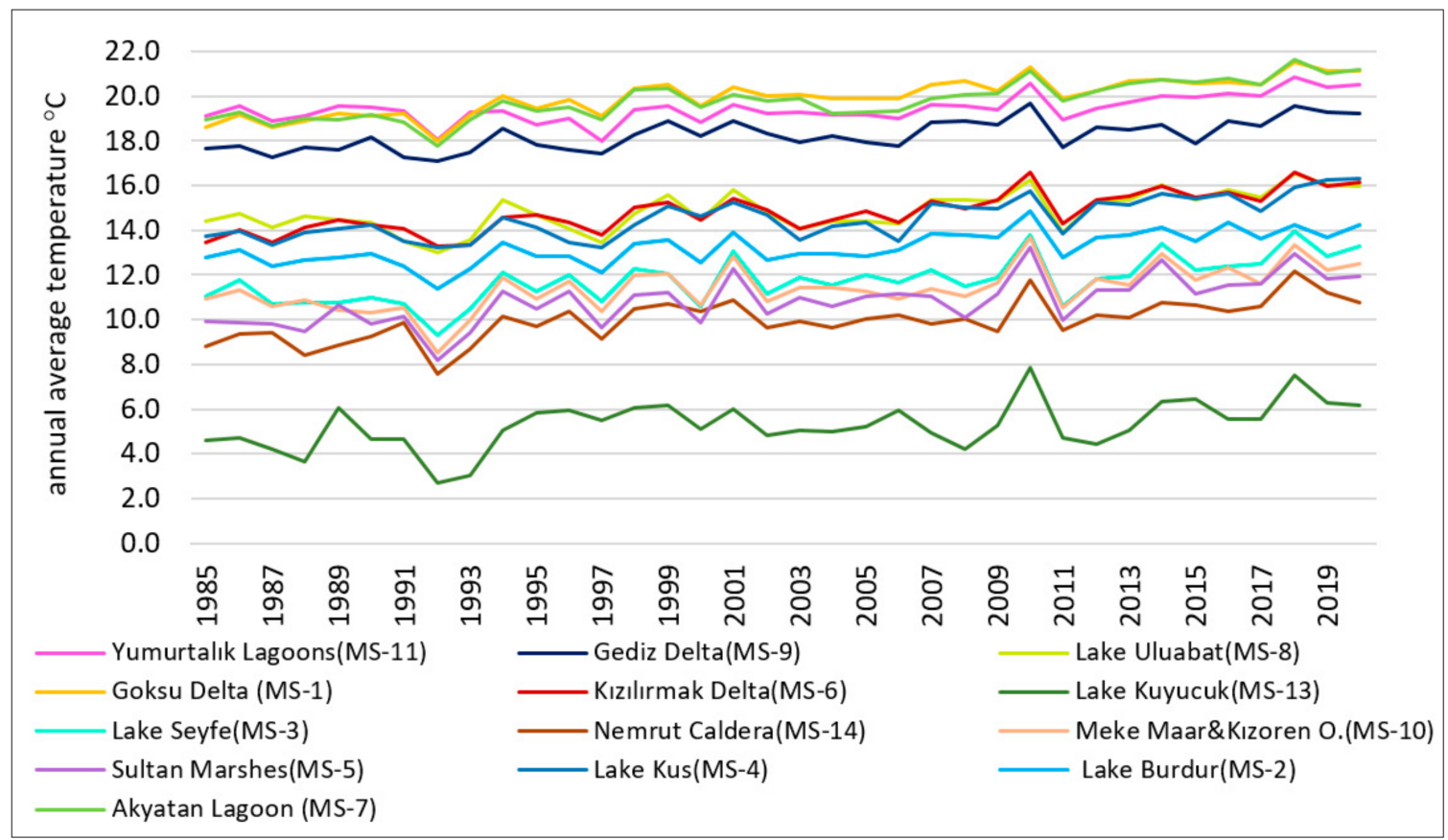

Figure 2. Long-term annual average temperatures representing the Ramsar Sites of Turkey.

Although there are great differences between the seasons and regions in Turkey, the long-term annual average total precipitation for 1981-2010 was $646 \mathrm{~mm}$. While there was a drought period in 2006, 2007, and 2008, positive anomalies were observed in precipitation between 2009 and 2012. In particular, 2009 was recorded as the wettest year with $804 \mathrm{~mm}$ precipitation, and 2008 was the driest year with $506 \mathrm{~mm}$. The average temperature, which was $12.7^{\circ} \mathrm{C}$ between 1970-1978, increased to $13.8^{\circ} \mathrm{C}$ between 2006 and 2012 [73].

The temperature data for 13 meteorology stations were examined, an upward trend was observed for all of them, and the average value of the 13 stations was $13.4{ }^{\circ} \mathrm{C}$ in 1985 and $15.3^{\circ} \mathrm{C}$ in 2020 .

The average precipitation and evaporation values, and evaporation/precipitation rates for the years 198-2020 are compiled in Table 6.

Table 6. Average precipitation and evaporation of 13 meteorological stations for 1985 to 2000.

\begin{tabular}{cccc}
\hline Ramsar Site & $\begin{array}{c}\text { 1985-2020 Average Annual } \\
\text { Evaporation (mm) }\end{array}$ & $\begin{array}{c}\text { 1985-2020 Average Annual } \\
\text { Precipitation (mm) }\end{array}$ & $\begin{array}{c}\text { 1985-2020 Rate } \\
\text { (Evaporation/Precipitation) }\end{array}$ \\
\hline Goksu Delta & 1253.54 & 617.93 & 2.02 \\
Lake Burdur & 1245.44 & 418.74 & 2.97 \\
Sultan Marshes & 1422.52 & 386.26 & 3.68 \\
Lake Kus (Manyas) & 1141.87 & 704.16 & 1.62 \\
Lake Seyfe & 1044.68 & 410.01 & 2.54 \\
Kizllirmak Delta & 836.91 & 721.40 & 1.16 \\
Akyatan Lagoon & 1561.91 & 558.26 & 2.70 \\
Lake Uluabat & 1149.62 & 707.13 & 1.63 \\
Gediz Delta & 1464.15 & 695.31 & 2.11 \\
MekeMaar and Kizoren O. & 1192.77 & 293.13 & 4.07 \\
Yumurtalik Lagoons & 1544.96 & 653.36 & 2.36 \\
Nemrut Caldera & 1072.99 & 401.38 & 2.67 \\
Lake Kuyucuk & 870.04 & 517.79 & 1.68 \\
\hline
\end{tabular}

When the Ramsar sites were evaluated according to their water surface areas, it can be seen that they had different water surface area sizes. The surface areas can be divided into three groups, those with a water surface area less than $100 \mathrm{ha}$, areas in the range of 
1000-10,000 ha, and large areas with 10,000 ha and above. There are three Ramsar sites under 100 ha, namely Meke Maar, Kizoren Obrouk, and Lake Kuyucuk. There are eight Ramsar areas between 1000 ha and 10,000 ha, and there are three with 10,000 ha and above, namely Lake Burdur, Lake Kus (Manyas), and Lake Uluabat. As marine/coastal Ramsar Sites interact with the sea and have different characteristics compared with inland Ramsar sites, they will be discussed in a different study, and the inland Ramsar Sites were analyzed in this study.

Digital elevation models (DEM) were created using Google Earth Pro elevation data to indicate the topography and altitude of the area from the sea level in the inland wetlands, and the water surface areas were shown on these models.

\subsection{Methods}

There are several techniques defining surface water extraction using Landsat data described in the literature. Water classification methods for optical imagery could be categorized into four basic types, namely thematic classification, linear unmixing, singleband thresholding, and spectral water indices [74]. Spectral indices are commonly preferred because of their ease of use and being computationally less time-consuming than others. Many indices have been developed specifically to exploit the unique spectral signature of water compared with other land cover types. NDWI was introduced in 1996 to delineate open water features using the green (Band 2) and near-infrared (Band 4) of Landsat TM [75]. A threshold value of zero was proposed for extracting surface water using the raw digital number of Landsat, where all positive NDWI values would be classified as water and negative values as non-water. Many studies comparing the other indices show that NDWI gives better results than the other indices [76-79]; therefore, NDWI was used to extract the water surface areas in this study. NDWI is expressed as follows [75]:

$$
\text { NDWI = Green-NIR/Green + NIR }
$$

where Green is a green band such as TM Band 2 (OLI, Band 3), and NIR is a near-infrared band such as TM Band 4 (OLI, Band 5).

\section{Results}

In Table 7, the water surface areas of inland Ramsar sites in spring are given for 1985, the designation years (DY), and 2020. The water surface areas of the Ramsar Sites in autumn are given in Table 8, for 1985, DY, and 2020. DY and 1985 were taken as the reference years and the changes in surface water areas were presented in ha (Table 7) and percentages (Figure 3) by comparing the surface area values from 1985 to DY, and DY to 2020 .

Table 7. The surface water areas of Ramsar sites in spring (1985, designation year (DY), and year 2020) and the changes.

\begin{tabular}{|c|c|c|c|c|c|c|c|}
\hline Ramsar Site & DY & $\begin{array}{c}1985 \text { Spring } \\
\text { (ha) }\end{array}$ & $\begin{array}{l}\text { DY Spring } \\
\text { (ha) }\end{array}$ & $\begin{array}{l}2020 \text { Spring } \\
\text { (ha) }\end{array}$ & $\begin{array}{c}\text { Change } \\
\text { (1985 to DY) } \\
\text { (ha) }\end{array}$ & $\begin{array}{l}\text { Change (DY } \\
\text { to 2020) (ha) }\end{array}$ & $\begin{array}{c}\text { Change } \\
\text { (1985 to 2020) } \\
\text { (ha) }\end{array}$ \\
\hline Lake Burdur & 1994 & $20,695.85$ & $17,811.51$ & $12,480.92$ & $(-) 2884.34$ & $(-) 5330.59$ & $(-) 8214.93$ \\
\hline Lake Seyfe & 1994 & 7743.39 & 5734.26 & 1656.87 & $(-) 2009.13$ & $(-) 4077.39$ & $(-) 6086.52$ \\
\hline Lake Kus (Manyas) & 1994 & $15,269.35$ & $15,308.37$ & $14,919.41$ & $(+) 39.02$ & $(-) 388.96$ & $(-) 349.94$ \\
\hline Sultan Marshes & 1994 & $10,184.56$ & 9577.84 & 5051.23 & $(-) 606.72$ & $(-) 4526.61$ & $(-) 5133.33$ \\
\hline Lake Uluabat & 1998 & $13,479.7$ & $14,974.43$ & $11,784.49$ & (+)1494.73 & $(-) 3189.94$ & $(-) 1695.21$ \\
\hline Meke Maar & 2005 & 71.26 & 50.75 & 2.17 & $(-) 20.51$ & $(-) 48.58$ & $(-) 69.09$ \\
\hline K1zören Obrouk & 2006 & 2.92 & 2.33 & 1.86 & $(-) 0.59$ & $(-) 0.47$ & $(-) 1.06$ \\
\hline Lake Kuyucuk & 2009 & 41.82 & 218.96 & 37.67 & $(+) 177.14$ & $(-) 181.29$ & $(-) 4.15$ \\
\hline Nemrut Caldera & 2013 & 1255.98 & 1254.23 & 1239.21 & $(-) 1.75$ & $(-) 15.02$ & $(-) 16.77$ \\
\hline Total (ha) & & $68,744.83$ & $64,932.68$ & $47,173.83$ & $(-) 3812.15$ & $(-) 17,758.90$ & $(-) 21,571.00$ \\
\hline $\begin{array}{l}\text { Total Percent } \\
\text { Change }(\%)\end{array}$ & & & & & $(-) 5.55$ & $(-) 27.35$ & $(-) 31.38$ \\
\hline
\end{tabular}


Table 8. The surface water areas of Ramsar Sites in autumn (1985, designation year (DY), and year 2020) and the changes.

\begin{tabular}{cccccccc}
\hline Ramsar Site & DY & $\begin{array}{c}\text { 1985 Au- } \\
\text { tumn } \\
\text { (ha) }\end{array}$ & $\begin{array}{c}\text { DY Autumn } \\
\text { (ha) }\end{array}$ & $\begin{array}{c}\text { 2020 Au- } \\
\text { tumn } \\
\text { (ha) }\end{array}$ & $\begin{array}{c}\text { Changes } \\
\text { (1985 to DY) } \\
\text { (ha) }\end{array}$ & $\begin{array}{c}\text { Changes } \\
\text { (DY to 2020) } \\
\text { (ha) }\end{array}$ & $\begin{array}{c}\text { Changes } \\
\text { (1985 to 2020) } \\
\text { (ha) }\end{array}$ \\
\hline Lake Burdur & 1994 & $20,544.35$ & $17,491.96$ & $12,349.11$ & $(-) 3052.39$ & $(-) 5142.85$ & $(-) 8195.24$ \\
Lake Seyfe & 1994 & 2775.78 & 2220.03 & 0 & $(-) 555.75$ & $(-) 2220.03$ & $(-) 2775.78$ \\
Lake Kus (Manyas) & 1994 & $12,939.21$ & $15,022.01$ & $14,569.03$ & $(+) 2082.8$ & $(-) 452.98$ & $(+) 1629.82$ \\
Sultan Marshes & 1994 & $3549.62 *$ & 3220.28 & 1602.01 & $(-) 329.34$ & $(-) 1618.27$ & $(-) 1947.61$ \\
Lake Uluabat & 1998 & $11,394.02$ & $11,573.3$ & $11,029.75$ & $(+) 179.28$ & $(-) 543.55$ & $(-) 364.27$ \\
Meke Maar & 2005 & 55.17 & 47.39 & 0 & $(-) 7.78$ & $(-) 47.39$ & $(-) 55.17$ \\
Kizoren Obrouk & 2006 & 2.55 & 2.26 & 2.14 & $(-)) 0.29$ & $(-) 0.12$ & $(-) 0.41$ \\
Lake Kuyucuk & 2009 & $3.97 *$ & 88.93 & 0 & $(+) 84.96$ & $(-)) 88.93$ & $(-) 3.97$ \\
Nemrut Caldera & 2013 & $1255.98 *$ & 1258.13 & 1235.21 & $(+) 2.15$ & $(-)) 22.92$ & $(-) 20.77$ \\
\hline Total (ha) & & $52,520.65$ & $50,924.29$ & $40,787.25$ & $(-) 1596.36$ & $(-) 10,137.04$ & $(-) 11,733.4$ \\
Total Percent & & & & & $(-) 3.04$ & $(-) 19.91$
\end{tabular}

$$
* 1986 \text {. }
$$

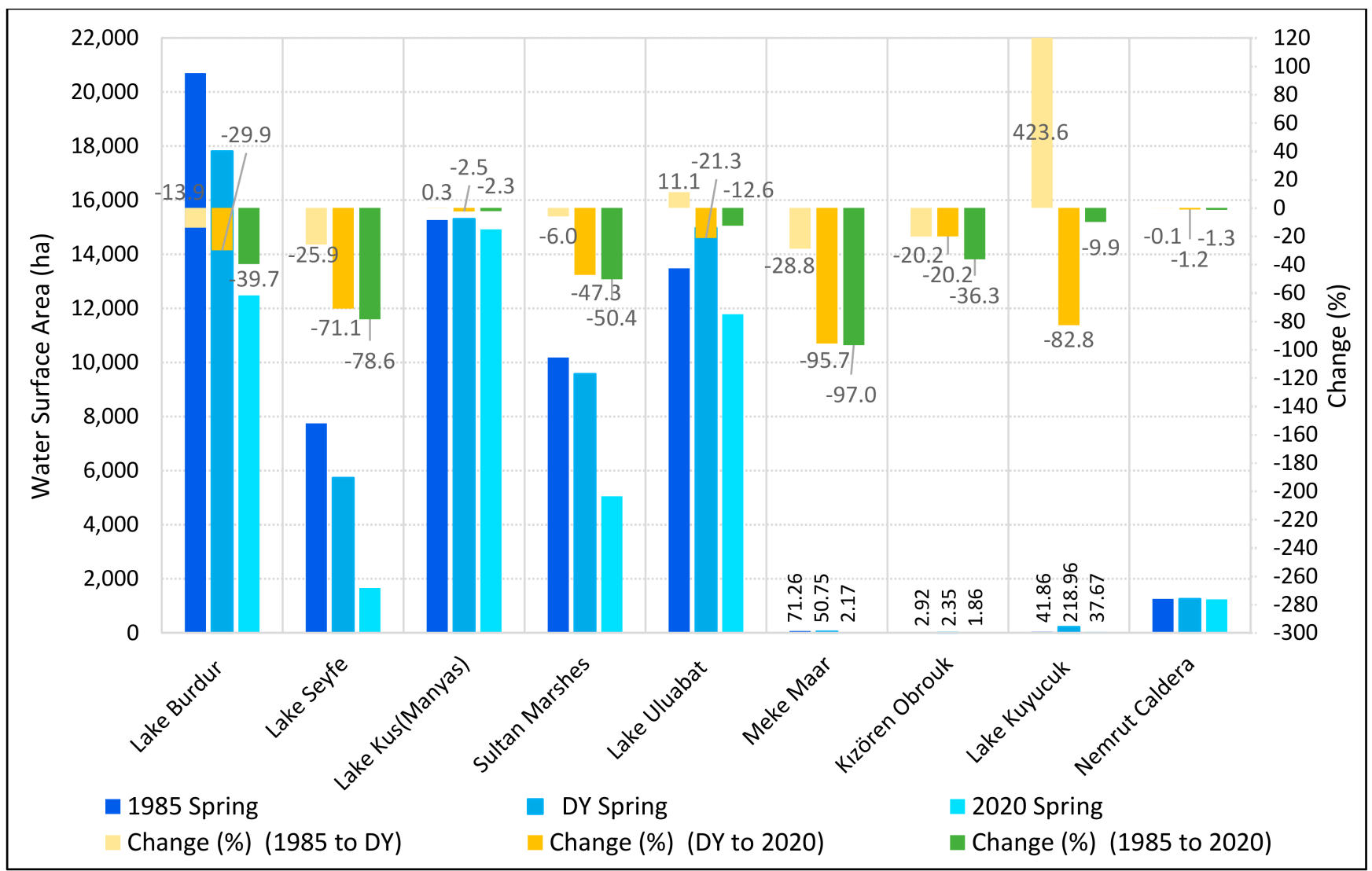

Figure 3. Water surface areas and changes from 1985 to DY and DY to 2020 (\%) in the inland Ramsar sites in spring.

When examining the water surface areas changes and percent changes for the spring months, we considered the following:

- The total water surface area in the inland Ramsar sites was 68,744.83 ha in 1985, and decreased to $47,173.83$ ha in 2020 . The change was $31.38 \%$ with a loss of $21,571.0$ ha. When the changes from 1985 to 2020 were examined, the biggest change in spatial terms occurred in Lake Burdur, with 8214.93 ha. The maximum percent change occurred in Meke Maar with 96.95\%. 
- 1985 to DY, which are given in Table 7, were examined, and the total change rate in all inland Ramsar sites was 5.55\% with 3812.15 ha. From 1985 to DY, there was a decrease in different rates in Lake Burdur, Lake Seyfe, Sultan Marshes, Meke maar, and Kizoren Obrouk, while there were different rates of increases in Lake Uluabat and Lake Kuyucuk. There was almost no change in Nemrut Caldera and Lake Kus (Manyas).

- The largest spatial change occurred in Lake Burdur, with a loss of 2884.34 ha from 1985 to 1994. The largest percent change occurred in Lake Kuyucuk with a gain of $423.58 \%$ in the period 1985 to 2009.

- The total change from DY to 2020 was $27.35 \%$ with a loss of $17,758.90$ ha. Reductions in the range of $0.01 \%$ to $100.00 \%$ occurred in all inland Ramsar sites. The largest areal loss occurred in Lake Burdur (5330.59 ha) from 1994 to 2020 and percent loss in Meke Maar (95.72\%).

When examining the water surface areas changes (Table 8) and percent changes (Figure 4) for the autumn months, we considered the following:

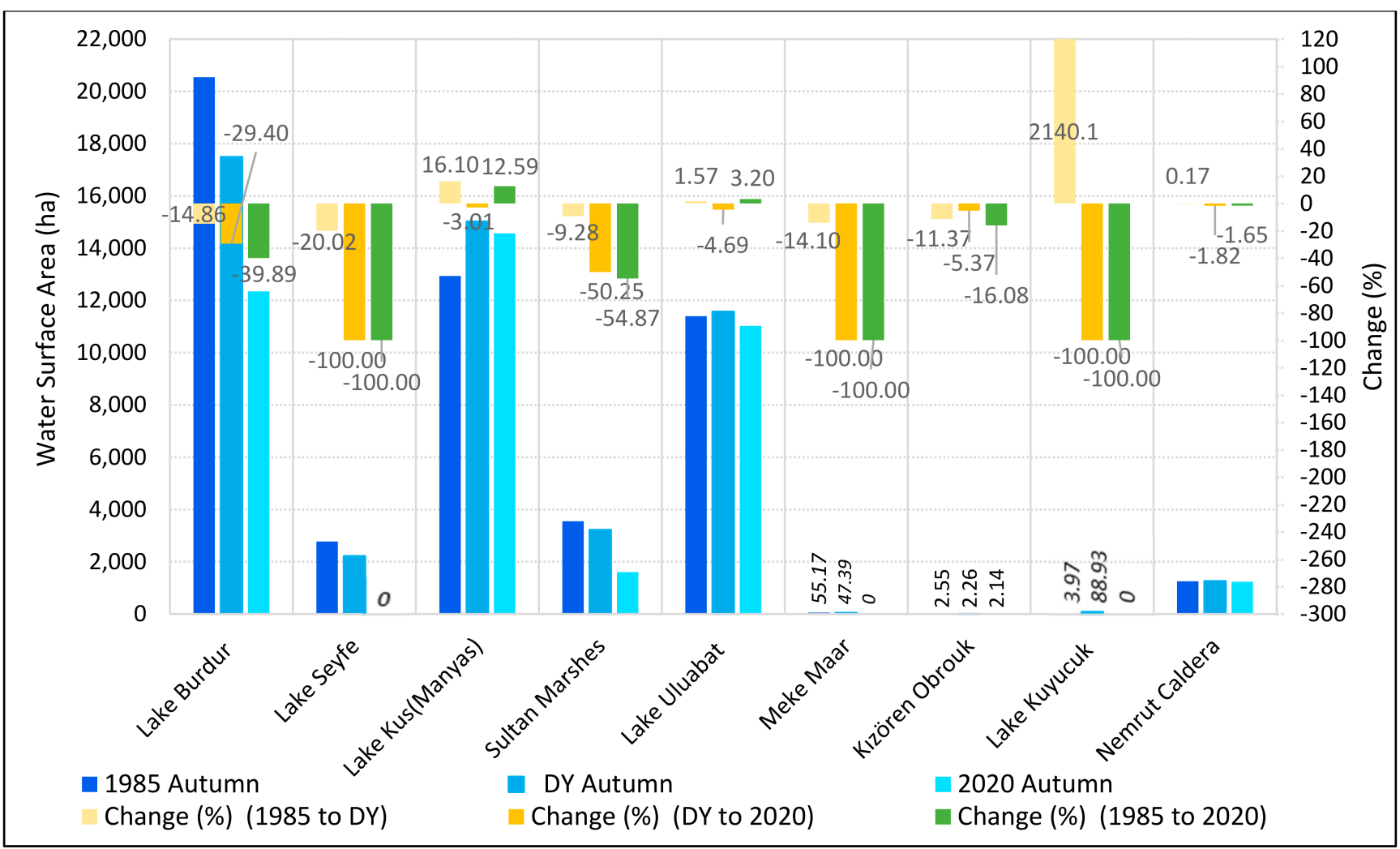

Figure 4. Water surface areas and changes from 1985 to DY and DY to 2020 (\%) in the inland Ramsar sites in autumn.

The total water surface area in all the inland Ramsar sites was 52,520.65 ha in 1985, and decreased to $40,787.25$ ha in 2020 . The change was $22.34 \%$ with a loss of $11,733.4$ ha. When the changes in inland wetlands from 1985 to 2020 were examined, only the area of Lake Kus (Manyas) was increased by $12.59 \%$ and all of the others decreased. In Lake Kus (Manyas), Meke Maar, and Lake Kuyucuk, the water completely disappeared.

- When the inland wetlands from 1985 to DY were examined, there was an increase of $16.10 \%$ (208.2.8 ha) in Lake Kus (Manyas), 1.57\% (179.28 ha) in Lake Uluabat, $0.17 \%$ (2.15 ha) in Nemrut Caldera, and 2140.05\% (84.96 ha) in Lake Kuyucuk. There was a decrease in the other sites.

- $\quad$ The change from DY to 2020 was $19.91 \%$ with a loss of 10,137.04 ha, there were spatial losses at different rates, and Lake Burdur ranked first with an area of 5142.85 ha. 
The areas in the different water surface area groups that underwent the most changes, Meke Maar, Lake Seyfe, and Lake Burdur, were evaluated together with the annual water surface area changes and annual meteorological data, as shown in Figures 5-7, respectively, between 1985-2020. When Tables 7 and 8 and Figures 3 and 4 are examined, it can be seen that the most dramatic percent change occurred in Lake Kuyucuk. Nemrut Caldera, on the other hand, was the area where the least change was seen in the spring and autumn months. The annual surface area changes of these two were examined between 1985 to 2020 with the annual water surface area changes and the meteorological parameters (Figures 8 and 9). The remaining four Ramsar sites were similarly examined (Figures 10-13).

Water surface areas in the Ramsar sites in the spring and autumn months of 1985, DY, and 2020 are given Figures 3 and 4, with percent change from 1985 to DY and from DY to 2020, and 1985 to 2020.

When the smaller Ramsar sites below 100 ha were examined, Meke Maar decreased the most from DY to 2020 in both spring and autumn. While there was a water surface area of 2.17 ha with a decrease of $95.72 \%$ from the spring months of 2005 to 2020 , it was completely dry in autumn 2020 (Figures 3 and 4).

Meke Maar, a crater lake formed by filling the islets in the middle of an extinct volcano crater [80], had the most significant change within the Ramsar sites. Its annual water surface area change for both the spring and autumn between 1985-2020, and the corresponding meteorological data representing the same terms, are given in Figure $5 a, b$, respectively. The water surface areas belonging to 1985, DY (2005), and 2020 are given on the produced DEM in Figure 5c. A photo from the Meke Maar is also added in Figure 5d.

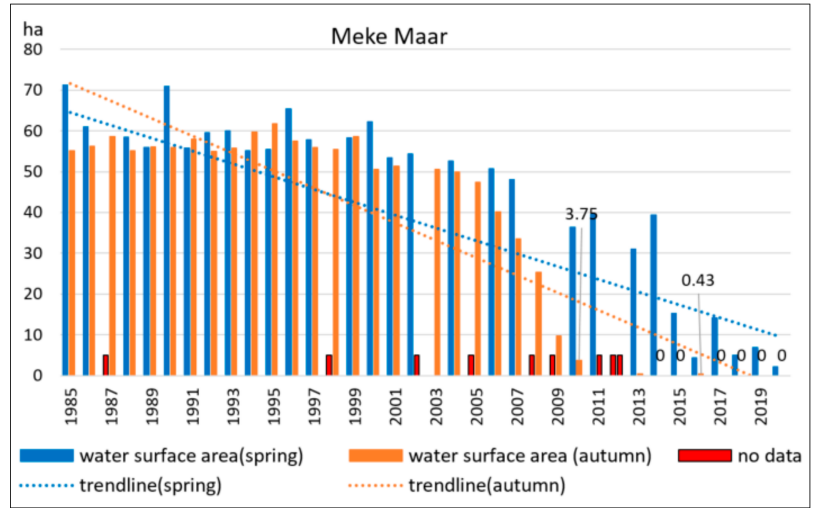

(a)

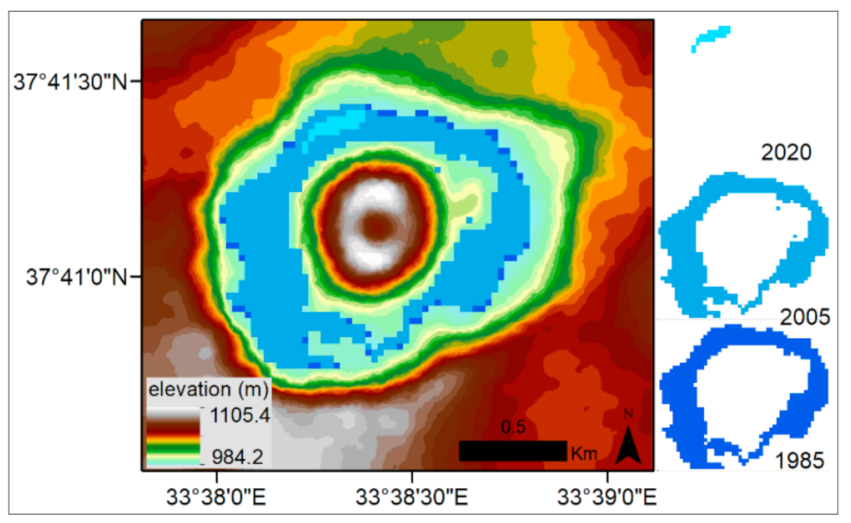

(c)

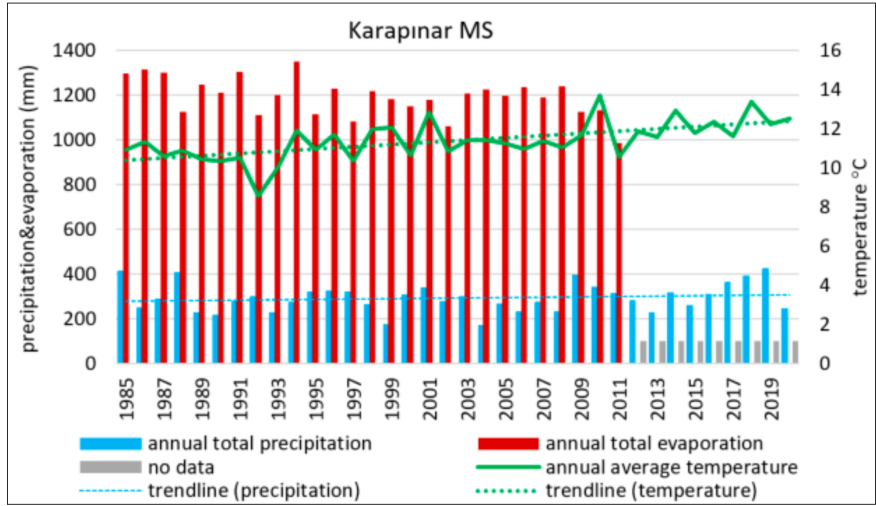

(b)

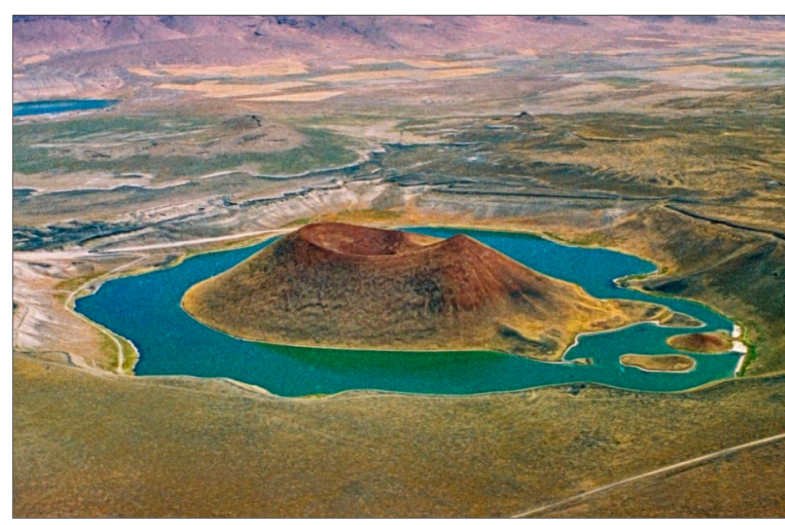

(d)

Figure 5. Meke Maar: (a) 1985-2020 annual (spring and autumn) surface water areas; (b) representative meteorological station data (precipitation, evaporation, and temperature); (c) water surface area change in spring (NDWI); (d) view of the maar [81]. 


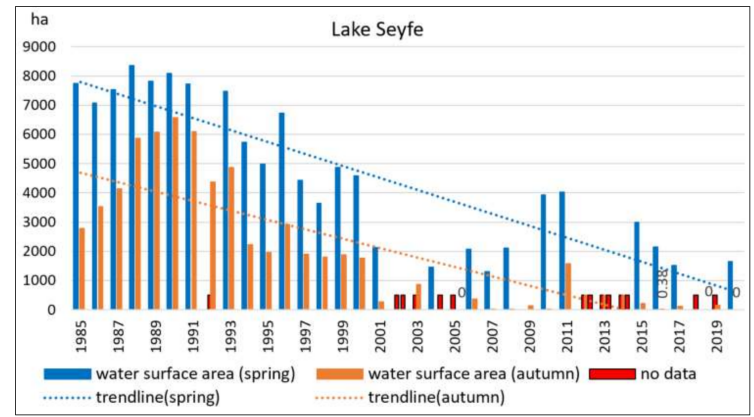

(a)

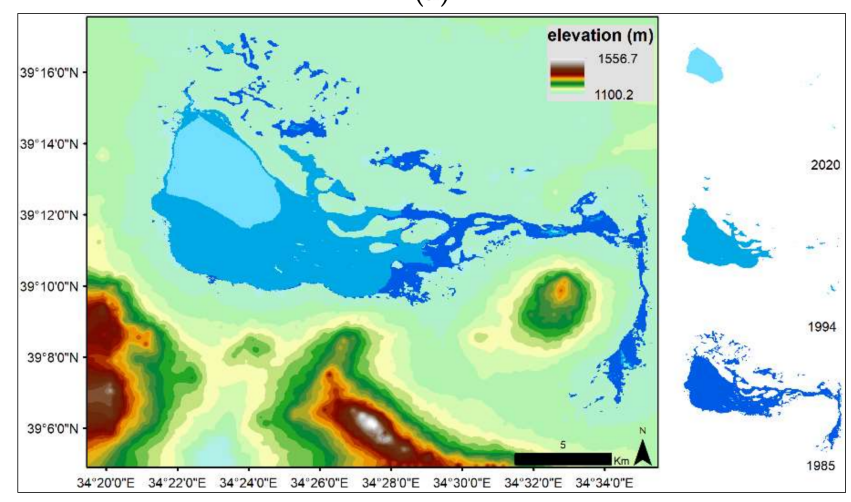

(c)

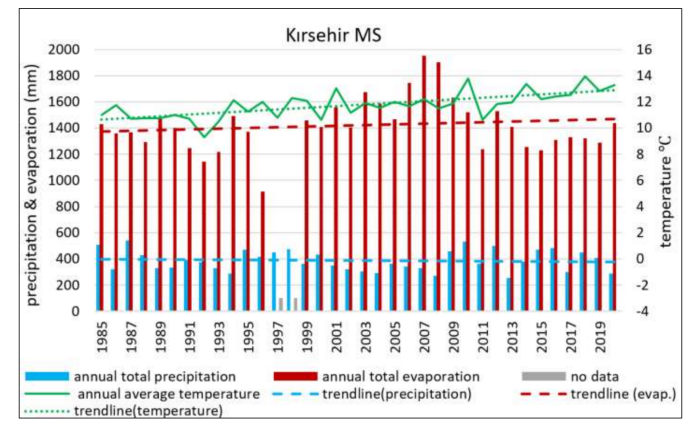

(b)

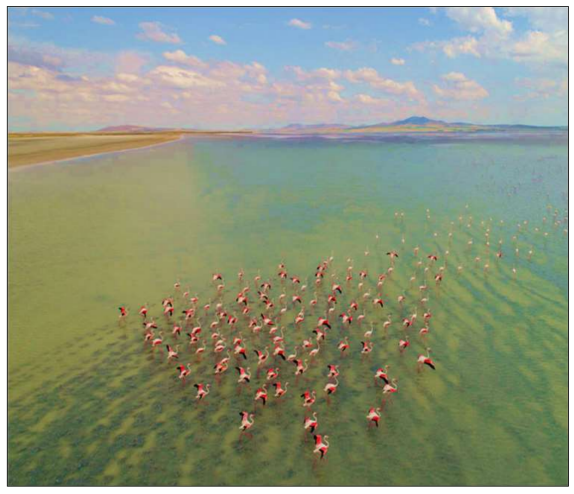

(d)

Figure 6. Lake Seyfe: (a) 1985-2020 annual (spring and autumn) surface water areas; (b) representative meteorological station data (precipitation, evaporation, and temperature); (c) water surface area change in spring (NDWI); (d) view of the lake [82].

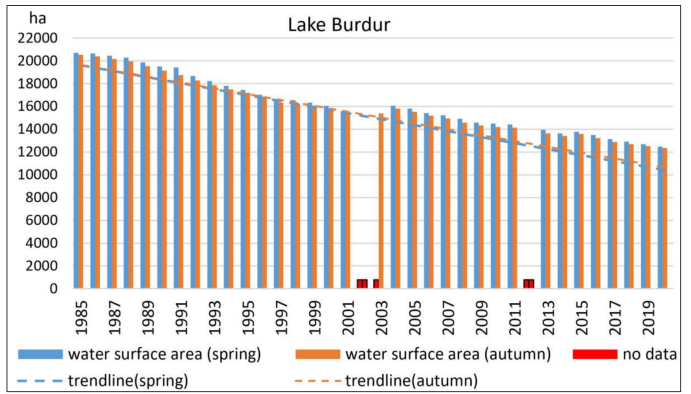

(a)

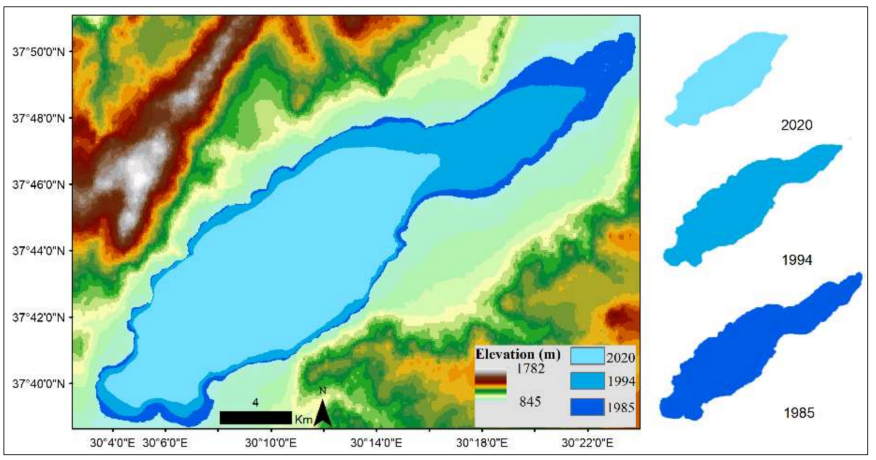

(c)

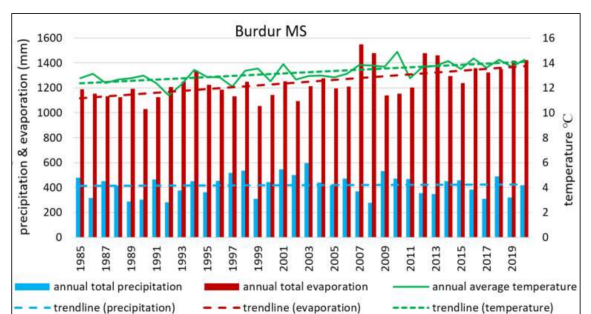

(b)

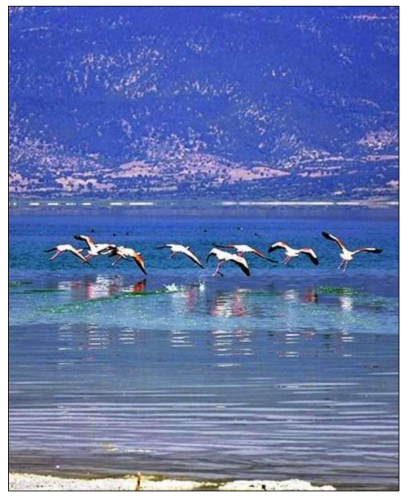

(d)

Figure 7. Lake Burdur: (a) 1985-2020 annual (spring and autumn) surface water areas; (b) representative meteorological station data (precipitation, evaporation, and temperature); (c) water surface a rea change in spring (NDWI); (d) view of the lake [83]. 


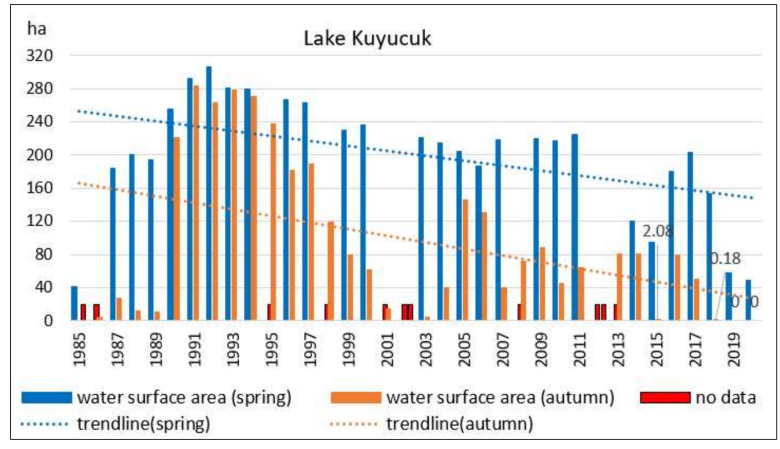

(a)

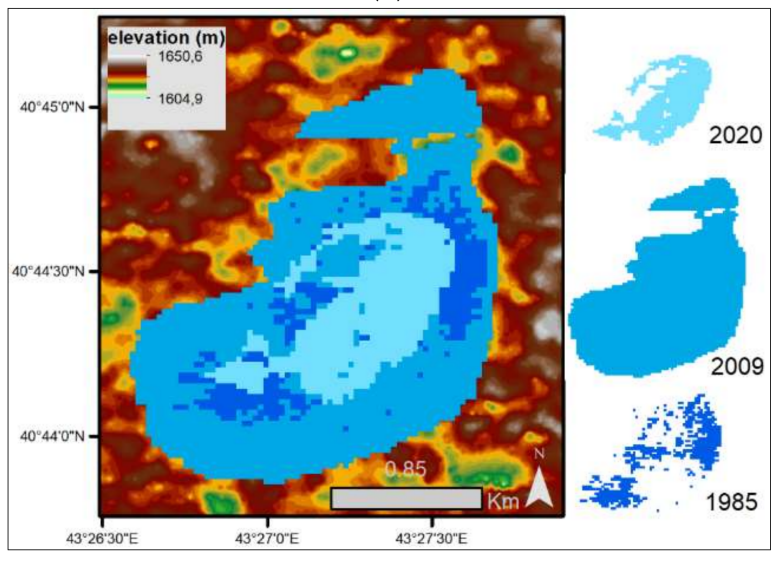

(c)

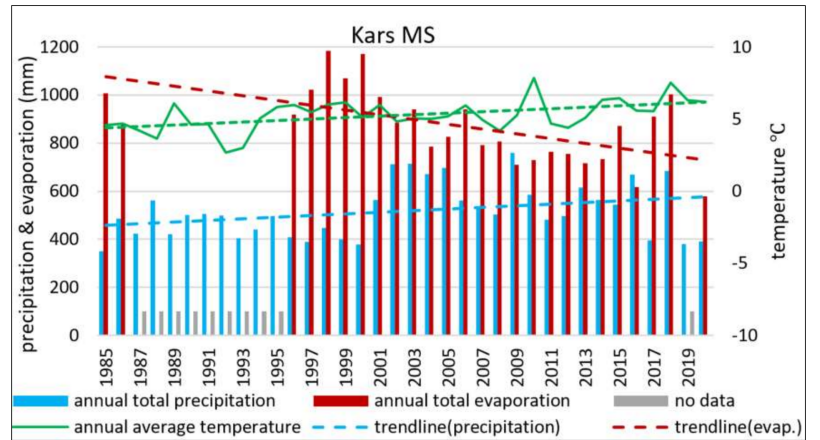

(b)

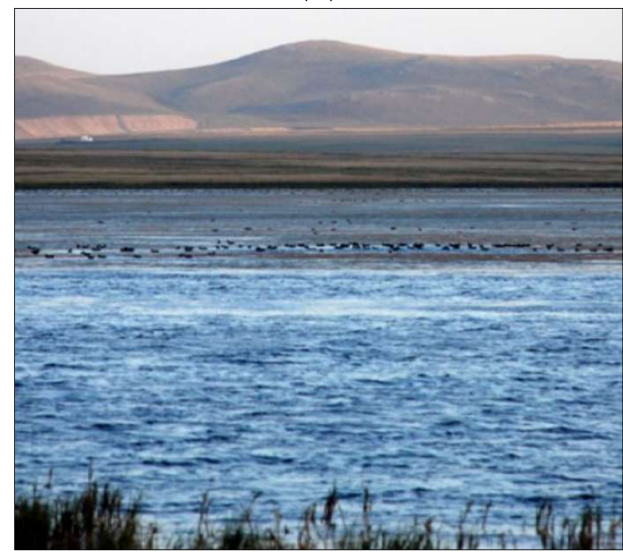

(d)

Figure 8. Lake Kuyucuk: (a) 1985-2020 annual (spring and autumn) surface water areas; (b) representative meteorological station data (precipitation, evaporation, and temperature); (c) water surface area changes (NDWI); (d) view of the lake [84].

The amount of water present decreased tremendously since 2005, as seen in Figure 5a. There was no water left in the autumn period from 2013. Considering the annual evaporation and precipitation values of the nearby meteorological station, the evaporation was approximately four times that of the precipitation (Table 6), as the averages of 35 years reflect that precipitation was $293.13 \mathrm{~mm}$, whereas evaporation was $1192.77 \mathrm{~mm}$. The average precipitation was less than half of Turkey's average $(646 \mathrm{~mm})$. The lack of water during the autumn months was basically due to the high evaporation. Even though there were no evaporation data available from 2012 to 2020, temperature values showed that there would be no expected change in evaporation. Similarly, there was also no change in the precipitation values since 2012. In this case, it can be highlighted that meteorological parameters were not the primary reason for water loss in the area. Primary reason for this change was the excessive withdrawal of groundwater for irrigational purposes [8].

When Ramsar sites in the range of 1000-10,000 ha were examined, the greatest decrease from DY to 2020 was seen in Lake Seyfe. While the decrease was $71.11 \%$ from DY (1994) to the spring months of 2020, it was observed that the area was completely dried in autumn. From 1985 to 2020, the total reduction rate was 78.6\% with 6086.52 ha. Lake Seyfe's annual water surface area change for both the periods of spring and autumn between 1985-2020, and the corresponding meteorological data from 1985 to 2020, are given in Figure 6a,b, respectively. The water surface areas belonging of 1985, designation year (1994), and 2020 are given in the produced DEM in Figure 5c. A view from the lake is added in Figure 6d.

The amount of water decreased tremendously since 1988 considering the 1985-2020 surface areas of Lake Seyfe (Figure 6a). When meteorological data were examined, according to the averages of 35 years, precipitation was $386.26 \mathrm{~mm}$, evaporation was $1422.52 \mathrm{~mm}$, and the amount of evaporation was approximately 3.6 times more than the precipitation. There was a decrease in water, especially in the autumn months, since 2001, as well as 
disappearances in some years related to low water levels and high evaporation rates. It was stated in the management plan [20] that the water level dropped to $60-70 \mathrm{~cm}$ in the summer season, most of which turned into salty swamp and even dried up due to the low rainfall of the region, and ended up with drying the streams feeding the lake and the high evaporation.

When the Ramsar areas of Turkey with an area of above 10,000 ha were examined, Burdur Lake was observed to have the largest water surface area in 1985. However, it has lost 8214.93 ha area with a $39.7 \%$ decrease from 1985 to 2020. In Lake Burdur, the rate of change from DY (1994) to 2020 was $29.9 \%$. It is one of the deepest lakes of the country, bearing a tectonic structure with a maximum depth of $110 \mathrm{~m}$ and an average depth of $40 \mathrm{~m}$ [19]. Lake Burdur's annual water surface area change for both spring and autumn for 1985-2020, and the meteorological station data from 1985 to 2020 are given in Figure 7a,b, respectively.

The water surface areas belonging to 1985, DY (1994), and 2020 are given on the produced DEM in Figure 7c, and a view of the lake is in Figure 7d.

Studies carried out in Burdur Lake have revealed that the lake water is salty and arsenic in proportions, and cannot be used as domestic and agricultural irrigation water [19]. Therefore, it has no agricultural or domestic use. When the graph showing the annual water surface areas in Figure 7 is examined, a decrease every year in the spring and autumn months can be seen. When the meteorological data were examined (Figure $7 \mathrm{~b}$ ), there was no noticeable change in the annual average precipitation trend, but there was an increase in temperature and evaporation over time. Looking at the averages of 35 years, precipitation was $418.7 \mathrm{~mm}$, while evaporation was $1245.44 \mathrm{~mm}$, indicating that evaporation was about three times more than precipitation.

In the Burdur Lake management plan [19], it was stated that the dams built on the rivers supplying water to the lake feeding were interrupted and that it was only fed by surface waters coming from precipitation, and the lake was rapidly shrinking as a result of the low precipitation and high evaporation rates.

When Figures 3 and 4 are examined, the biggest change can be seen from DY to 2020 in the spring and autumn months in Lake Kuyucuk, while there was almost no change in Nemrut Caldera.

The annual water surface area changes for both spring and autumn of Lake Kuyucuk between 1985-2020, as well as the Kars meteorological station data from 1985 to 2020, are given in Figure 8a,b, respectively. The water surface areas of 1985, to the designation year (2009), to year 2020 are given on the produced DEM in Figure 8c. A photo from the lake is added in Figure 9d.

Lake Kuyucuk is a small freshwater lake located in the middle of a slightly wavy open land, fed by small springs, streams, and precipitations; its deepest point is $13 \mathrm{~m}$ [21]. When the annual water surface areas of Lake Kuyucuk were examined, water was seen in the spring months, while the amount of water decreased in some years in autumn, while in some years there was no water left. It has been reported that floods occurred in the region in some years because of excessive rainfall, and the lake area was filled; however, the effective volume of the lake decreased because of the transfer of sediment to the lake through overflows [21]. The reason for the excessive amount of water in the area in DY 2009 was because it was the year with the highest rainfall between 1985-2020 (Figure 8b). The construction of a dam (Kars) nearby Lake Kuyucuk started in 2010, and the water retention in this dam lake started in July 2018 [85]. From this date onwards, there was no water left in Kuyucuk Lake in autumn (Figure 8a). 


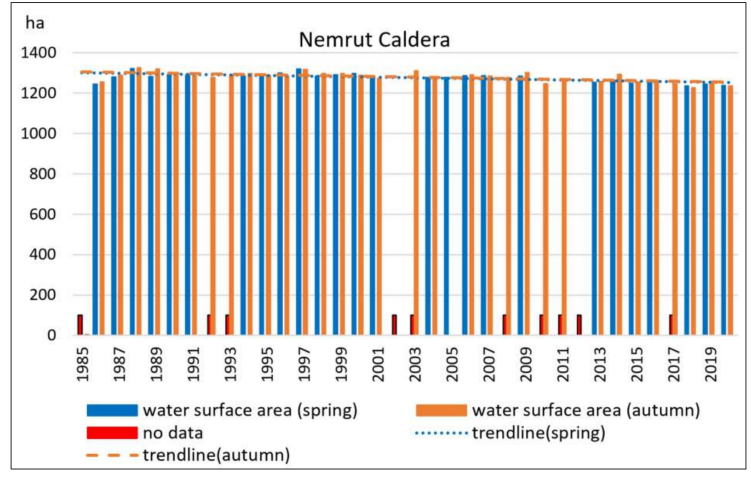

(a)

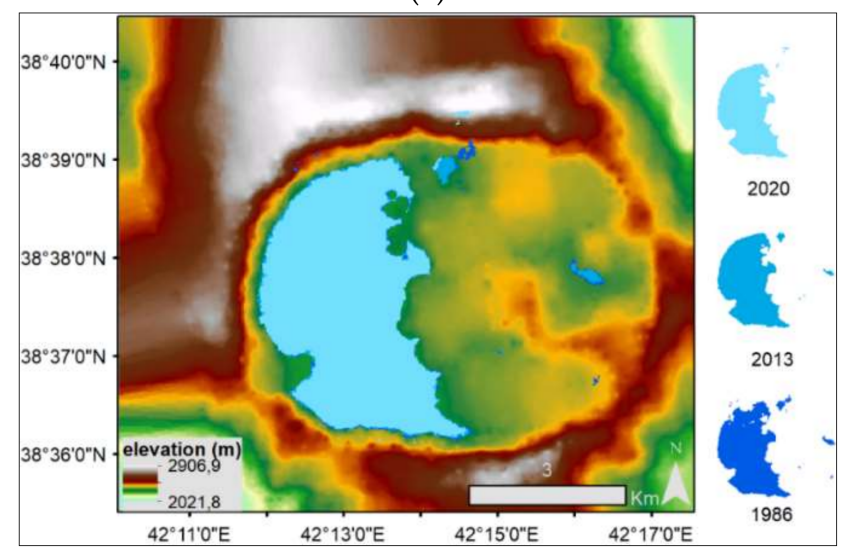

(c)

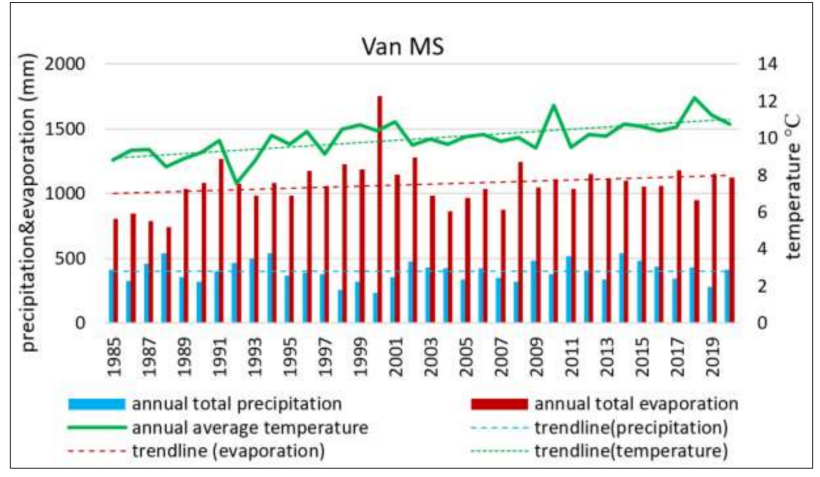

(b)

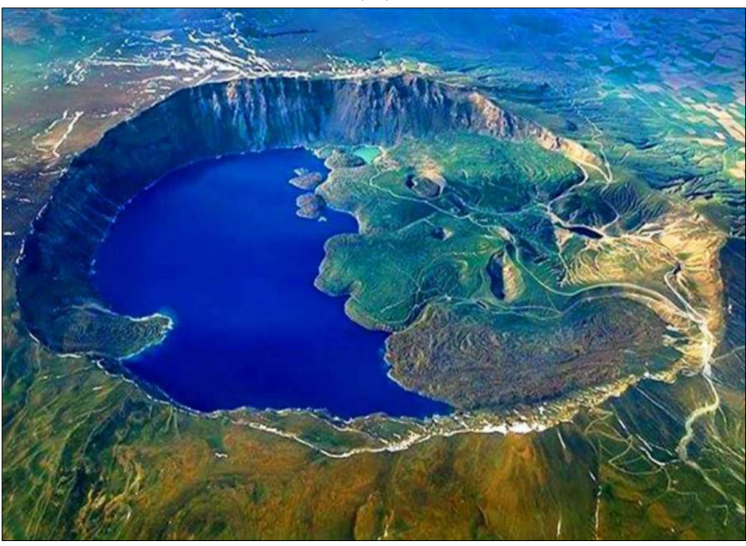

(d)

Figure 9. Nemrut Caldera: (a) 1985-2020 annual (spring and autumn) surface water areas; (b) representative meteorological station data (precipitation, evaporation, and temperature); (c) water surface area changes (NDWI); (d) view of the site [86].

The Ramsar site where the water surface area changed the least was the Nemrut Caldera, as shown in Figure 9a. There was a decrease of $-1.3 \%$ from 1985 to 2020 (Figure 3). Its annual water surface area changed for both spring and autumn between 1985-2020, and the representative meteorological station data from 1985 to 2020 are given in Figure 9a,b, respectively. The water surface areas belonging to 1985, DY (2013), and 2020 are given on the produced DEM in Figure 9c. A photo from the Nemrut Caldera is added in Figure 9d.

Nemrut Mountain is known as one of the largest craters of the world, with a width of about $10 \mathrm{~km}$. The Crater Lake located on the mountain is the second-largest caldera lake in the world [87]. The western half of the base is covered with a lake. There are five lakes at the summit, two of which are continuous, and three are seasonal. The largest of the Nemrut lakes is the Nemrut Lake in the shape of a half-moon. The average depth of this lake is around $100 \mathrm{~m}$. As the lake is far from settlements, there are no structures and facilities nearby that may cause pollution [11]. When the graph showing the annual water surface areas in Figure 9a is examined, it can be seen that there was a slight decrease every year in both the spring and autumn months. When the meteorological data were examined (Figure 9b), there was no noticeable change in the annual total precipitation trend, but there was an increase in temperature and evaporation over time. Over the average of 35 years, precipitation was $401.38 \mathrm{~mm}$, while evaporation was $1072.99 \mathrm{~mm}$, indicating that evaporation was about 2.67 times more than precipitation. Therefore, the increased evaporation trend can be considered a factor in reducing the water surface area. However, although the caldera is a closed basin and there is no outflow from the rivers, there is a noticeable decrease in the water level and this should be investigated [87]. 


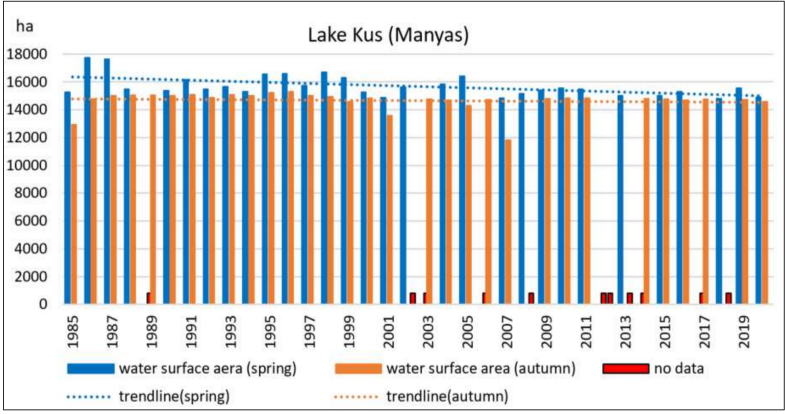

(a)

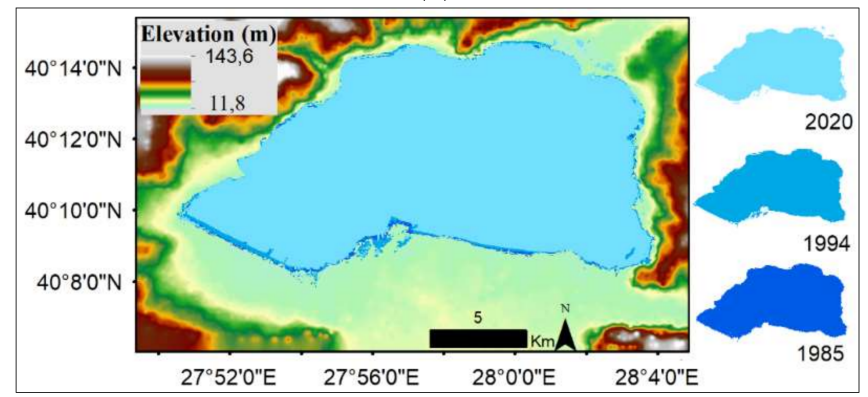

(c)

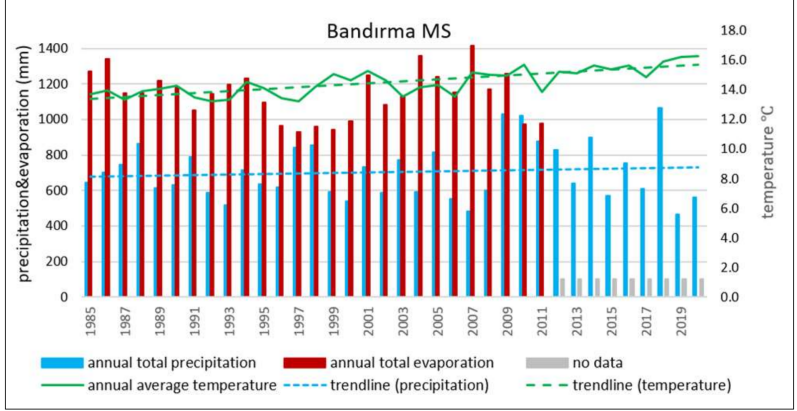

(b)

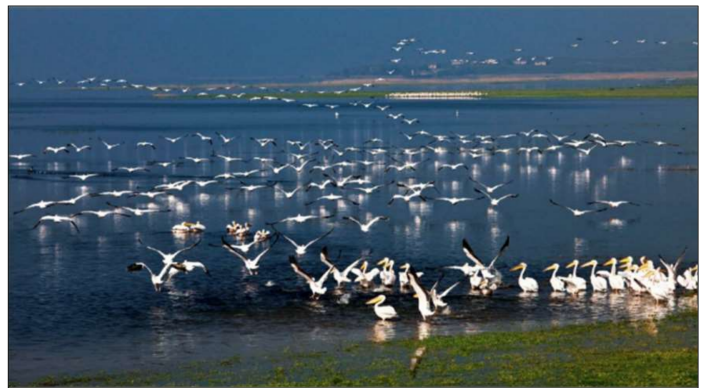

(d)

Figure 10. Lake Kus (Manyas): (a) 1985-2020 annual (spring and autumn) surface water areas; (b) representative meteorological station data (precipitation, evaporation, and temperature); (c) water surface area changes (NDWI); (d) view of the site [88].

Lake Kus (Manyas) is the second-largest Ramsar site in terms of water surface area after Burdur Lake. The lake is a broad and shallow freshwater lake with an average depth of $3 \mathrm{~m}$. Its water is always turbid because it contains colloidal clay. Lake Manyas, which is very rich in plankton and bottom creatures, has allowed for the development of wildlife. Lake Manyas is the first area to be recognized as a "bird paradise" in Turkey, so it pioneered the recognition of birds, wetlands, and nature. Lake Manyas's annual water surface area change for both spring and autumn between 1985-2020, as well as the representative meteorological station data from 1985 to 2020, are given in Figure 10a,b, respectively. The water surface areas belonging to 1985, DY (1994), and 2020 are given in the produced DEM in Figure 10c. A photo from the Lake Kus (Manyas) is added in Figure 10d.

When the graph showing the annual water surface areas in Figure 10a is examined, it can be seen that there was a decrease every year in the spring, and the trend did not change much in the autumn months. When the meteorological data were examined (Figure 10b), an increase in the annual total precipitation trend and temperature was found. The average precipitation ( 35 years) was $704.16 \mathrm{~mm}$ and the average evaporation (27 years) was $1141.87 \mathrm{~mm}$, indicating that evaporation was about 1.62 times more than precipitation. While the lake had a water surface area of $15,269.35$ ha in 1985 , it decreased to $14,919.41$ ha with a $2.3 \%$ loss in 2020 . The main reason for the high water level difference in the spring and autumn months is the withdrawal of water from the lake for agricultural activities [10].

Lake Uluabat is the third-largest Ramsar Site in Turkey; it is located on the bird migration route entering Anatolia from the northwest, and is the lake with the most extensive lotus beds in Turkey. The deepest part of the lake is $6 \mathrm{~m}$, and it is a turbid, eutrophic freshwater lake. The water resources at and around the lake, as well as the small streams that reach the lake during rainy periods, keep the water level in balance [89]. Lake Uluabat annual water surface area change for both spring and autumn between 1985-2020, as well as the representative meteorological station data from 1985 to 2020, are given in Figure 11a,b, respectively. The water surface areas belonging to 1985, DY (1998), and 2020 are given on the produced DEM in Figure 11c. A photo from Lake Uluabat is added in Figure 11d [90]. 


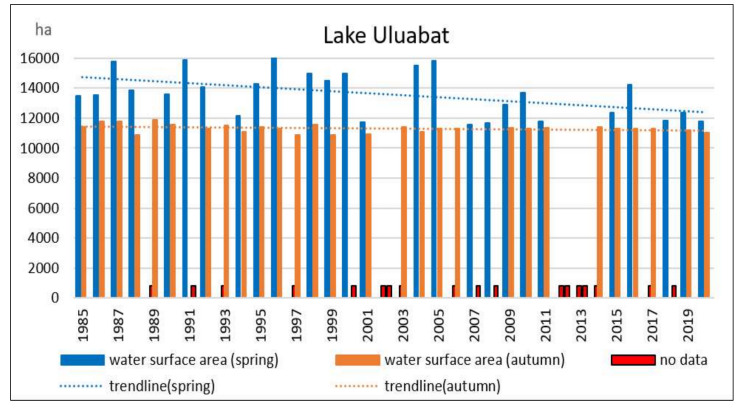

(a)

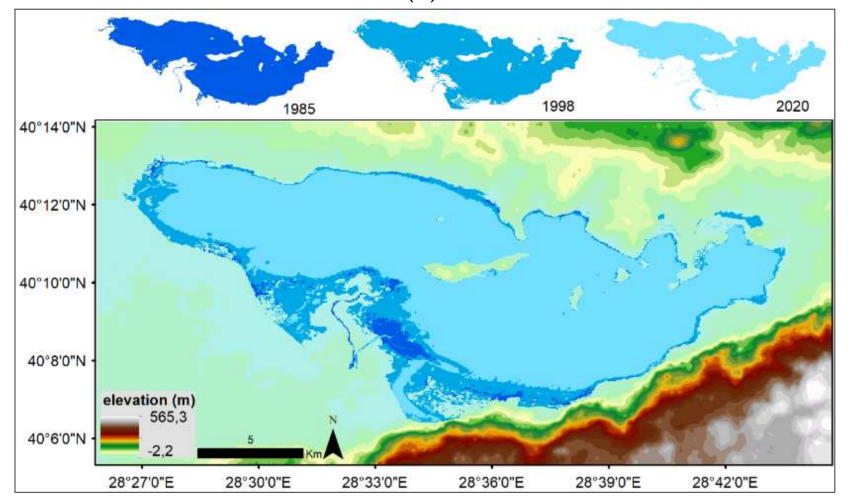

(c)

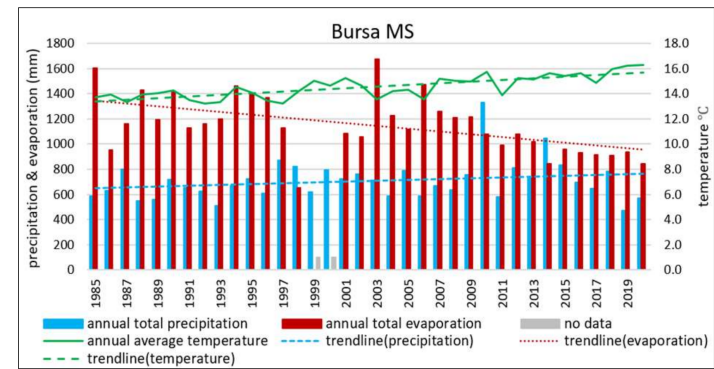

(b)

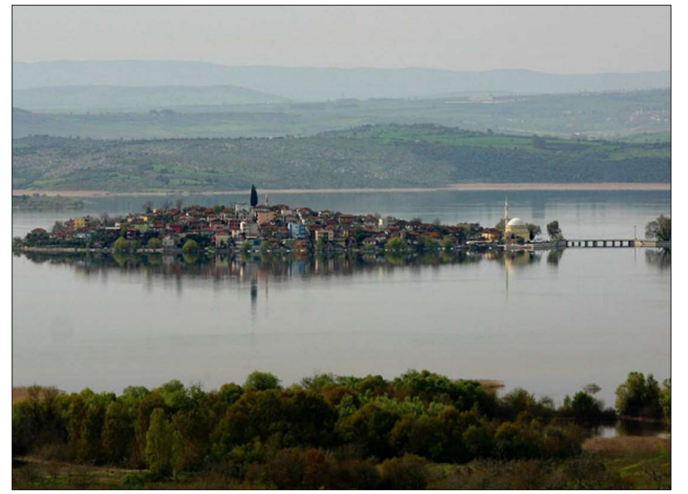

(d)

Figure 11. Lake Uluabat: (a) 1985-2020 annual (spring and autumn) surface water areas; (b) representative meteorological station data (precipitation, evaporation, and temperature); (c) water surface area changes (NDWI); (d) view of the site [90].

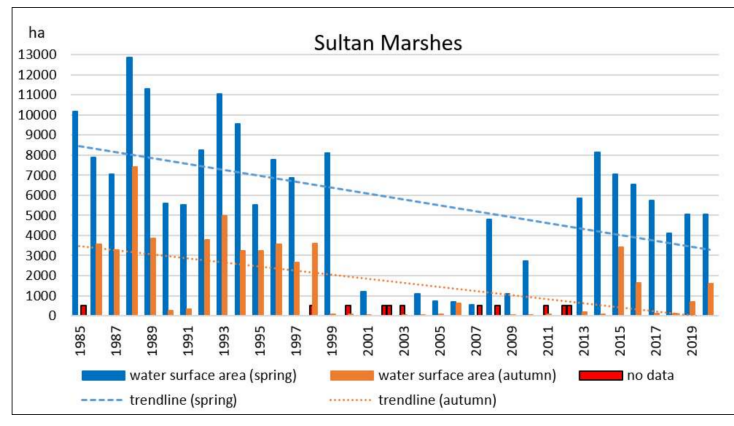

(a)

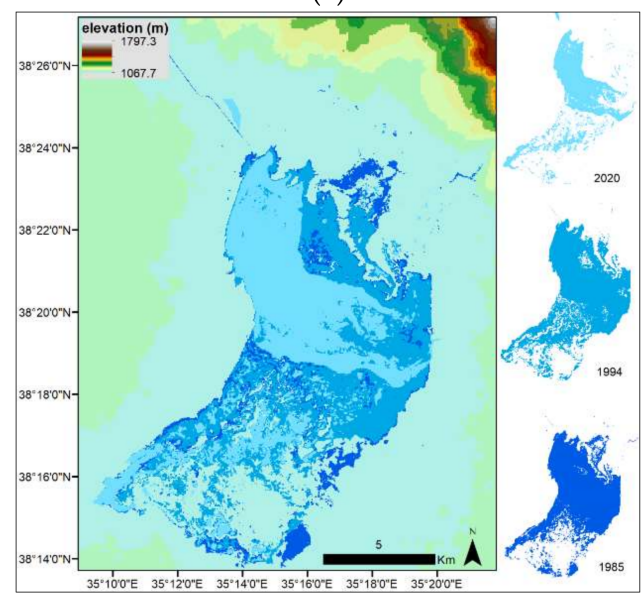

(c)

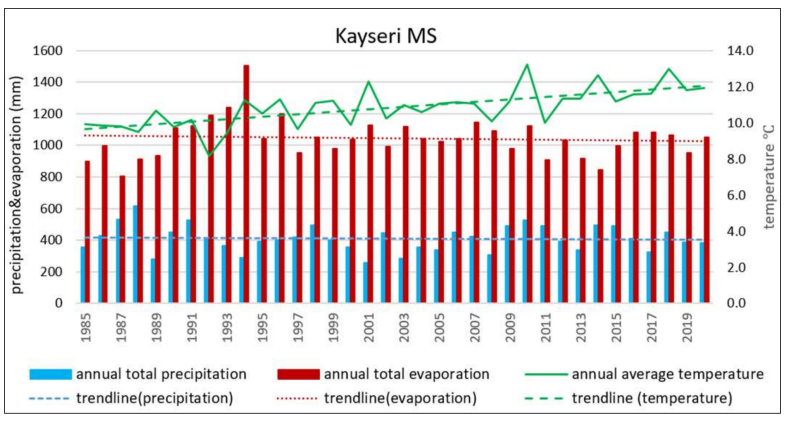

(b)

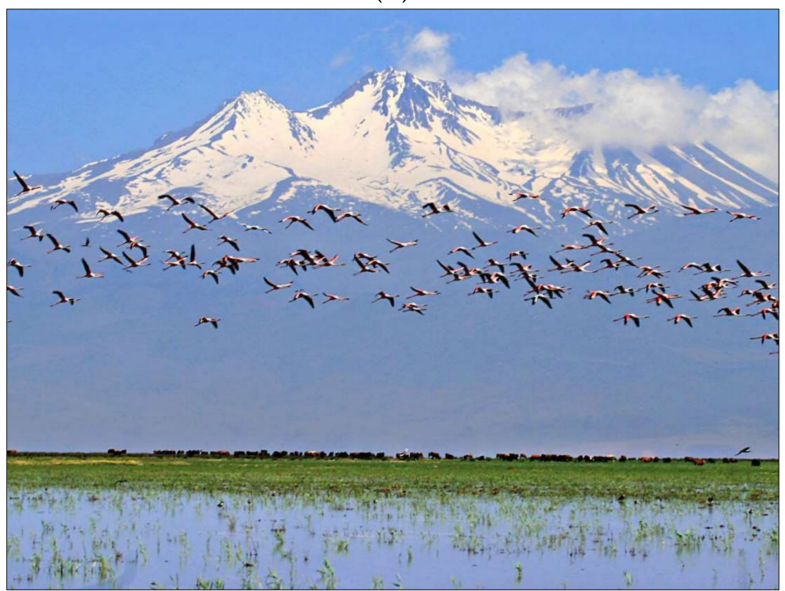

(d)

Figure 12. Sultan Marshes: (a) 1985-2020 annual (spring and autumn) surface water areas; (b) representative meteorological station data (precipitation, evaporation, and temperature); (c) water surface area changes (NDWI); (d) view of the site [91]. 


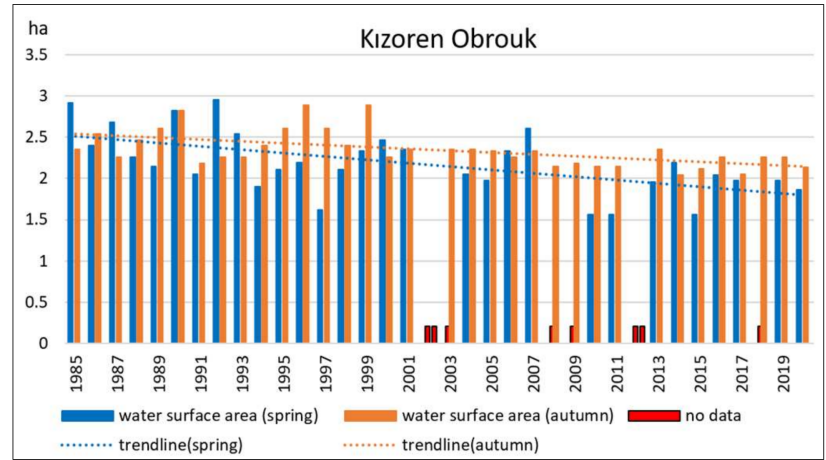

(a)

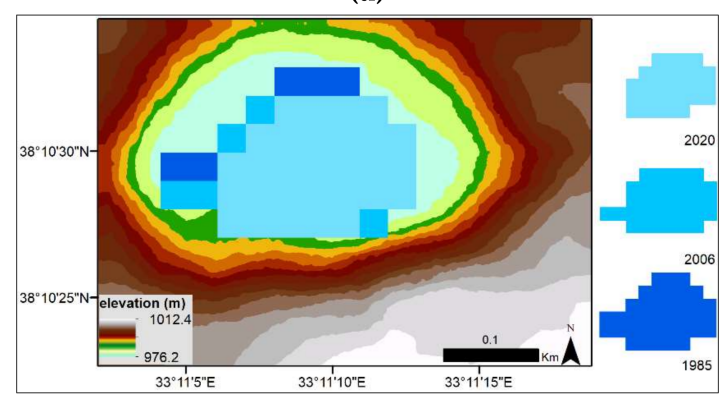

(c)

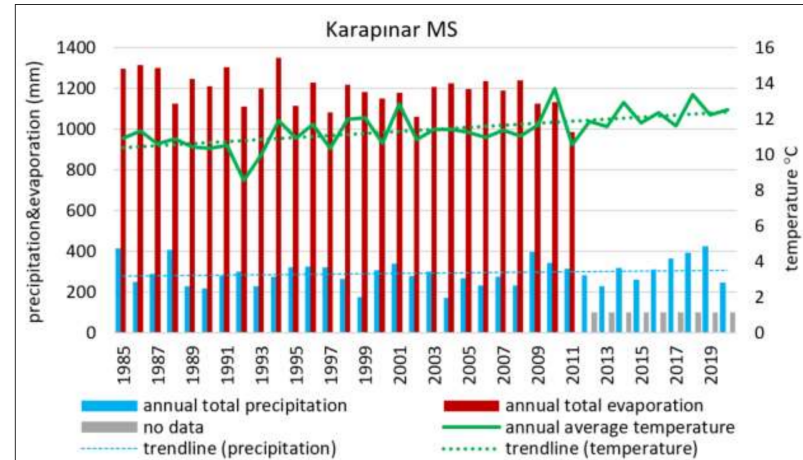

(b)

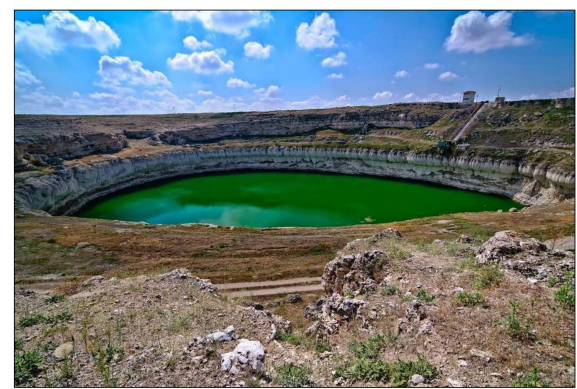

(d)

Figure 13. Kizoren Obrouk: (a) 1985-2020 annual (spring and autumn) surface water areas; (b) representative meteorological station data (precipitation, evaporation, and temperature); (c) water surface area changes (NDWI); (d) view of the site [92].

When the graph showing the annual water surface areas in Figure 11a is examined, it can be seen that there was a decreasing trend in the spring, and the trend did not change much in the autumn months. When the meteorological data were examined (Figure 11b), there was an increase in the annual total precipitation trend and annual average temperature. A decreasing trend was observed in evaporation. The average for precipitation (35 years) was $707.13 \mathrm{~mm}$, and the average for evaporation (32 years) was $1149.62 \mathrm{~mm}$, indicating that the evaporation was about 1.63 times more than precipitation. While the lake had a water surface area of 13,479.7 ha in 1985, it decreased to $11,784.49$ ha with a $12.6 \%$ loss in 2020 . The area covered by the lake is shrinking because of the drainage waters coming from the agricultural areas and the sediment load carried by the streams. Environmental risks continue in the lake, whose water quality has deteriorated due to pollution, and protection cannot be provided to sustain the biodiversity in the lake $[10,14]$.

Sultan Marshes is a rare ecosystem where fresh and saltwater ecosystems coexist and form the feeding, sheltering, and hatching area of 301 bird species, including endangered species. Its annual water surface area changes for both spring and autumn between 19852020, as well as the representative meteorological station data from 1985 to 2020, are given in Figure 12a,b. The water surface areas belonging to 1985, DY (1994), and 2020 are given on the produced DEM in Figure 12c. A photo from the Sultan Marshes is added in Figure 12d.

When the graph showing the annual water surface areas in Figure 12a is examined, it can be seen that there was a decrease every year in both the spring and autumn months. In general, the water surface area became small in the autumn months and even decreased to almost non-existence in some years. Furthermore, when the meteorological data were examined (Figure 12b), there were decreases in the annual total evaporation trend. On the other hand, the annual average temperature trend increased as in other meteorological stations, and a stable precipitation trend was observed below the average for Turkey. After the all-year meteorological data were examined, precipitation was $386.26 \mathrm{~mm}$ while evaporation was $1422.52 \mathrm{~mm}$, indicating that evaporation was about 3.68 times more than precipitation. 
The increase in population, the expansion of agricultural areas as much as possible, and the inclusion of irrigated agricultural products in field agriculture significantly deteriorated the ecosystem. Water is supplied to the fields from the dams on the springs feeding the Sultan Marshes, and some of it is recycled to the lakes through drainage channels. However, with the increase in the water required for agricultural activities, sufficient water cannot be sent to the lakes, which is the main reason for the drying up of Sultan Marshes [10,17].

The Kizoren obrouk, which has the smallest surface area among the Ramsar Sites, is one of about twenty obrouks in the Konya Closed Basin, with a width of $300 \mathrm{~m}$ and a depth of $145 \mathrm{~m}$. As in other obrouks, the water color, which is dark blue and green in the first months of summer, turns into a clear indigo color as the summer progresses. The Kizoren obrouk annual water surface area change for both spring and autumn periods between 1985-2020, as well as the representative meteorological station data from 1985 to 2020, are given in Figure 13a,b, respectively. The water surface areas belonging to 1985, DY (2006), and 2020 are given on the produced DEM in Figure 13c. A photo from the obrouk is added in Figure 13d.

Because of their formation, the obrouks have the same level of water as the groundwater. The water level decreased significantly in Kizoren Obrouk, as in other lakes in the Konya Basin, where the groundwater level drops to a depth of $45 \mathrm{~m}$. In the past, the level of obrouk water was at a level that a pump could draw. Decreased groundwater due to the intensive agricultural activities carried out in the Konya Closed Basin also reduced the level of the obrouk water, making it impossible to draw water from the obrouks [10]. The water level, which was only 1-2 $\mathrm{m}$ from the surface in 1988, is now $28 \mathrm{~m}$ below the surface level [93]. When the graph showing the annual water surface areas in Figure 13a is examined, it can be seen that there was a decrease every year both in the spring and autumn months. In addition, the graph shows that there is more water surface area in autumn than in spring. The reason for this is the decrease in the groundwater level in the spring months due to agricultural irrigation. Because of the narrowing structure of the obrouk, the water surface area decreases as the water level decreases.

\section{Discussion}

The water surface area change in Turkey's inland Ramsar sites was investigated over a 35-year period. In general, there was a decrease in all Ramsar sites in various ratios from 1985 to 2020. As can be summarized in Table 4, all Ramsar Sites are faced with numerous threats. After reviewing the related articles, reports, and management plans, improper water use can be accounted as the main reason underlying the decrease in the water surface area, except for Burdur Lake, where water cannot be used for domestic and agricultural usage. Human interventions without considering the balance of protection threaten the existence of these areas; therefore, the ecosystem services they offer are decreasing day by day.

When the meteorological parameters related to the changes in the Ramsar areas were examined, it was seen that the decrease in water surface areas in many sites was also related to meteorological events. During the 35-year period, although there was no extreme change in general, there was an increase in the amount of evaporation at some stations, and no significant change was observed in the precipitation trend. In general, the amount of reduction was higher in areas with high evaporation/precipitation rates. When the temperature data for 13 meteorological stations were examined, an upward trend was observed for all of them, and the average value increase was $1.9^{\circ} \mathrm{C}$ in 35 years.

The Turkish State Meteorological Service produces regional climate projections using global model outputs such as RCP (Representative Concentration Pathway), RegCM4 (Regional Climate Model-4), and the downscaling method [73]. Model outputs were produced by selecting the period of 1971-2000 as the reference period, and 2013-2099 for the projections. These studies indicate that temperatures in Turkey will increase by 0.5 to $3.0^{\circ} \mathrm{C}$ until 2050, and 0.5 to $4.0^{\circ} \mathrm{C}$ until 2100 with the optimistic scenario (RCP 4.5). According 
to the pessimistic scenario (RCP 8.5), the expected increase will be higher; by 0.9 to $3.5^{\circ} \mathrm{C}$ until 2050, and by 0.9 to $6.3^{\circ} \mathrm{C}$ until 2100 . In terms of precipitation amounts, as stated in the optimistic scenario, positive anomalies are expected throughout the country until 2040-2050. After these years, decreases are expected in the average precipitation; as the number of evaporation increases with the increase in temperature, the danger of drying increases in shallow wetlands. Although a two-dimensional image analysis was performed for the surface area changes in this study, the water volume for the maintenance and stability of wetlands, which is planned in the continuation of this study, should be taken into account.

As the change in the water cycle that will occur due to climate change will affect water resources, it is essential to protect/manage wetlands in a rational way in order not to destroy them. Regarding the protection/management of these areas, many areas have more than one protection status (as shown in Table 4). In almost all wetlands of Turkey, management plans were prepared gradually, and protection zones were determined with the obligations arising from the Ramsar Convention and national laws. Management plans of twelve Ramsar Sites have been completed (Table 4), and plans for Kizoren Obrouk and Meke Maar are under preparation. However, with this study, it has been revealed that there were significant aerial losses in the inland wetlands from the dates they were declared Ramsar sites until 2020. In addition, when the implementation dates of management plans in Table 4 are compared with the water surface area graphs of the sites, it can be seen that the water surface areas decreased after the management plans were revealed and put into implementation. In the presence of these management plans and multiple protection statuses, the loss seen is thought-provoking. This results from the fact that these plans are not effective enough, they are not taken into account by society, and the process is not well managed by the authorities. Consequently, these areas have not been adequately protected, and management plans are not fully implemented.

\section{Conclusions}

It is crucial to adopt the rational use principle for protecting wetlands and to prepare the management plans of the areas accordingly. The management plan should be understood as the fundamental law that organizes all conservation and utilization activities to be carried out within the wetlands of concern. To maintain the protection-utilization balance, all stakeholders benefiting from the wetland should adopt the area where they live; continue their economic activities; and act with awareness of the economic, social, and ecological importance of such areas. For this reason, effective communication and cooperation between relevant institutions and organizations, local governments, and non-governmental organizations at every stage of the preparation and implementation of wetland management plans is necessary so that disputes are resolved, and compromise and coordination are provided. Many of the Ramsar sites are affiliated with different ministries or directorates, as they have more than one protection status simultaneously, resulting in a confusion of authority in the management of the sites. This issue should be taken into account and resolved first.

Another critical issue is that the developments should be monitored and reviewed concurrently with the implemented wetland management plans. Monitoring shows the progress wetland management plans have made towards achieving their goals, making it easier to identify whether everything is in order and whether adaptation is required for facing the dynamic conditions. Unfortunately, there has not yet been an established mechanism for monitoring wetland management plans in Turkey. As seen in this study, remote sensing tools and methods are of great importance in monitoring wetlands and determining changes, so they should be used effectively by relevant institutions and organizations for sustainable management and conservation.

Funding: This research received no external funding.

Data Availability Statement: Not applicable. 
Acknowledgments: I would like to thank S. Serhan Çağırankaya, Ayşegül Tanık, A.Filiz Sunar and Ecem Bengisu Dervişoğlu for their support.

Conflicts of Interest: The author declares no conflict of interest.

\section{References}

1. Brander, L.; Schuyt, K. The Economic Values of the World's Wetlands; WWF International: Amsterdam, The Netherlands, 2004; Available online: https://www.cbd.int/financial/values/g-value-wetlands.pdf (accessed on 20 January 2021).

2. Ramsar.org. Available online: https://www.ramsar.org/sites/default/files/documents/library/factsheet3_global_disappearing_ act_0.pdf (accessed on 20 January 2021).

3. Davidson, N.C. Ramsar convention on wetlands: Scope and implementation. In The Wetland Book I: Structure and Function, Management, and Methods; Springer: Berlin/Heidelberg, Germany, 2018; pp. 451-458.

4. Ramsar.org. Available online: https://www.ramsar.org/about/international-cooperation (accessed on 20 January 2021).

5. Ramsar.org. Available online: https://www.ramsar.org/sites/default/files/documents/library/ramsarsites_criteria_eng.pdf (accessed on 15 January 2021).

6. Doğanyiğit, R. Tabi Göller ve Sulak Alanlar Konusunda Yürütülen Çalışmalar; Su Yönetimi Genel Müdürlügü: Ankara, Turkey, 2016.

7. Ramsar.org. Available online: https://rsis.ramsar.org/ (accessed on 10 February 2021).

8. WWF.org.tr. Evaluation Report Ramsar Site in Turkey. Istanbul, Turkey. 2008. Available online: http:/ /awsassets.wwftr.panda. org/downloads/wwf_turkiye_ramsar_alanlari_degerlendirme_raporu.pdf (accessed on 5 January 2021).

9. Dugan, P.J. Wetland Conservation: A Review of Current Issues and Required Action. Gland, Switzerland. 1990. Available online: https:/ / portals.iucn.org/library/node/6048 (accessed on 1 March 2021).

10. Dogadernegi.org. Available online: https://www.dogadernegi.org/wp-content/uploads/2015/08/T\%C3\%BCrkiyenin-RamsarAlanlar\%C4\%B1nda-Sulak-Alan-Y\%C3\%B6netim-Planlar\%C4\%B1-De\%C4\%9Ferlendirme-Raporu_Bask\%C4\%B1.pdf (accessed on 2 February 2021).

11. WWF.org.tr. Available online: https://wwftr.awsassets.panda.org/downloads/2subatbilginotu.pdf?1401/sulakalanarimizinkor unmasi (accessed on 2 April 2021).

12. Goksu Delta Management Plan; General Directorate of Nature Conservation and National Parks of the Ministry of Agriculture and Forestry: Ankara, Turkey, 2008.

13. Kus Lake (Manyas) Management Plan; General Directorate of Nature Conservation and National Parks of the Ministry of Agriculture and Forestry: Ankara, Turkey, 2018.

14. Lake Uluabat Managemet Plan; General Directorate of Nature Conservation and National Parks of the Ministry of Agriculture and Forestry: Ankara, Turkey, 2015.

15. Gediz Delta Management Plan (2019-2023); General Directorate of Nature Conservation and National Parks of the Ministry of Agriculture and Forestry: Ankara, Turkey, 2019.

16. Kizılırmak Delta Management Plan; General Directorate of Nature Conservation and National Parks of the Ministry of Agriculture and Forestry: Ankara, Turkey, 2015.

17. Sultan Marshes Management Plan; General Directorate of Nature Conservation and National Parks of the Ministry of Agriculture and Forestry: Ankara, Turkey, 2007.

18. Yumurtalık Lagoons Management Plan; General Directorate of Nature Conservation and National Parks of the Ministry of Agriculture and Forestry: Ankara, Turkey, 2007.

19. Burdur Lake Management Plan; General Directorate of Nature Conservation and National Parks of the Ministry of Agriculture and Forestry: Ankara, Turkey, 2018.

20. Lake Seyfe Management Plan; General Directorate of Nature Conservation and National Parks of the Ministry of Agriculture and Forestry: Ankara, Turkey, 2017.

21. Kuyucuk Lake Management Plan; General Directorate of Nature Conservation and National Parks of the Ministry of Agriculture and Forestry: Ankara, Turkey, 2017.

22. Akyatan Lagoon 2018 Management Plan; General Directorate of Nature Conservation and National Parks of the Ministry of Agriculture and Forestry: Ankara, Turkey, 2018.

23. Nasa.gov. Available online: https://landsat.gsfc.nasa.gov/landsat-1-3/landsat-1 (accessed on 20 January 2021).

24. Johnston, R.M.; Barson, M.M. Remote sensing of Australian wetlands: An evaluation of Landsat TM data for inventory and classification. Mar. Freshw. Res. 1993, 44, 235-252. [CrossRef]

25. Frohn, R.C.; Reif, M.; Lane, C.; Autrey, B. Satellite remote sensing of isolated wetlands using object-oriented classification of Landsat-7 data. Wetlands 2009, 29, 931-941. [CrossRef]

26. Baker, C.; Lawrence, R.L.; Montagne, C.; Patten, D. Change detection of wetland ecosystems using Landsat imagery and change vector analysis. Wetlands 2007, 27, 610-619. [CrossRef]

27. De Roeck, E.R.; Verhoest, N.E.; Miya, M.H.; Lievens, H.; Batelaan, O.; Thomas, A.; Brendonck, L. Remote sensing and wetland ecology: A South African case study. Sensors 2008, 8, 3542-3556.

28. Kayastha, N.; Thomas, V.; Galbraith, J.; Banskota, A. Monitoring wetland change using inter-annual landsat time-series data. Wetlands 2012, 32, 1149-1162. [CrossRef] 
29. Verpoorter, C.; Kutser, T.; Tranvik, L. Automated mapping of water bodies using Landsat multispectral data. Limnol. Oceanogr. Methods 2012, 10, 1037-1050. [CrossRef]

30. Tulbure, M.G.; Broich, M. Spatiotemporal dynamic of surface water bodies using Landsat time-series data from 1999 to 2011. ISPRS J. Photogramm. Remote Sens. 2013, 79, 44-52. [CrossRef]

31. Dong, Z.; Wang, Z.; Liu, D.; Song, K.; Li, L.; Jia, M.; Ding, Z. Mapping wetland areas using Landsat-derived NDVI and LSWI: A case study of West Songnen plain, Northeast China. J. Indian Soc. Remote Sens. 2014, 42, 569-576. [CrossRef]

32. Jones, J.W. Efficient wetland surface water detection and monitoring via landsat: Comparison with in situ data from the everglades depth estimation network. Remote Sens. 2015, 7, 12503-12538. [CrossRef]

33. Han, X.; Chen, X.; Feng, L. Four decades of winter wetland changes in Poyang Lake based on Landsat observations between 1973 and 2013. Remote Sens. Environ. 2015, 156, 426-437. [CrossRef]

34. Banerjee, B.P.; Raval, S.; Timms, W. Evaluation of rainfall and wetland water area variability at Thirlmere Lakes using Landsat time-series data. Int. J. Environ. Sci. Technol. 2016, 13, 1781-1792. [CrossRef]

35. Xie, H.; Luo, X.; Xu, X.; Pan, H.; Tong, X. Evaluation of Landsat 8 OLI imagery for unsupervised inland water extraction. Int. J. Remote Sens. 2016, 37, 1826-1844. [CrossRef]

36. Dervisoglu, A.; Dervisoglu, A.; Musaoglu, N.; Tanik, A.; Seker, D.Z.; Kaya, S. Satellite-based temporal assessment of a dried lake: Case study of Akgol Wetland. Fresenius Environ. Bull 2017, 26, 352-359.

37. Yagmur, N.; Bilgilioglu, B.B.; Dervisoglu, A.; Musaoglu, N.; Tanik, A. Long and short-term assessment of surface area changes in saline and freshwater lakes via remote sensing. Water Environ. J. 2021, 35, 107-122. [CrossRef]

38. Jin, H.; Huang, C.; Lang, M.W.; Yeo, I.Y.; Stehman, S.V. Monitoring of wetland inundation dynamics in the Delmarva Peninsula using Landsat time-series imagery from 1985 to 2011. Remote Sens. Environ. 2017, 190, 26-41. [CrossRef]

39. Schaffer-Smith, D.; Swenson, J.J.; Barbaree, B.; Reiter, M.E. Three decades of Landsat-derived spring surface water dynamics in an agricultural wetland mosaic; Implications for migratory shorebirds. Remote Sens. Environ. 2017, 193, 180-192.2020. [CrossRef]

40. Mejia Ávila, D.; Soto Barrera, V.C.; Martínez Lara, Z. Spatio-temporal modelling of wetland ecosystems using Landsat time series: Case of the Bajo Sinú Wetlands Complex (BSWC)-Córdoba-Colombia. Ann. GIS 2019, 25, 231-245. [CrossRef]

41. Yang, L.; Wang, L.; Yu, D.; Yao, R.; He, Q.; Wang, S.; Wang, L. Four decades of wetland changes in Dongting Lake using Landsat observations during 1978-2018. J. Hydrol. 2020, 587, 124954. [CrossRef]

42. Mao, D.; Wang, Z.; Du, B.; Li, L.; Tian, Y.; Jia, M.; Zeng, Y.; Song, K.; Jiang, M.; Wang, Y. National wetland mapping in China: A new product resulting from object-based and hierarchical classification of L8 OLI images. ISPRS J. Photogramm. Remote Sens. 2020, 164, 11-25. [CrossRef]

43. Li, Z.; Sun, W.; Chen, H.; Xue, B.; Yu, J.; Tian, Z. Interannual and Seasonal Variations of Hydrological Connectivity in a Large Shallow Wetland of North China Estimated from Landsat 8 Images. Remote Sens. 2021, 13, 1214. [CrossRef]

44. Wang, X.; Xiao, X.; Zou, Z.; Hou, L.; Qin, Y.; Dong, J.; Doughty, R.B.; Chen, B.; Zhang, X.; Chen, Y.; et al. Mapping coastal wetlands of China using time-series Landsat images in 2018 and Google Earth Engine. ISPRS J. Photogramm. Remote Sens. 2020, 163, 312-326. [CrossRef] [PubMed]

45. Gorelick, N.; Hancher, M.; Dixon, M.; Ilyushchenko, S.; Thau, D.; Moore, R. Google Earth Engine: Planetary-scale geospatial analysis for everyone. Remote Sens. Environ. 2017, 202, 18-27. [CrossRef]

46. Pekel, J.F.; Cottam, A.; Gorelick, N.; Belward, A.S. High-resolution mapping of global surface water and its long-term changes. Nature 2016, 540, 418-422. [CrossRef] [PubMed]

47. Wang, R.; Xia, H.; Qin, Y.; Niu, W.; Pan, L.; Li, R.; Zhao, X.; Bian, X.; Fu, P. Dynamic Monitoring of Surface Water Area during 1989-2019 in the Hetao Plain Using Landsat Data in Google Earth Engine. Water 2020, 12, 3010. [CrossRef]

48. Chen, J.; Kang, T.; Yang, S.; Bu, J.; Cao, K.; Gao, Y. Open-Surface Water Bodies Dynamics Analysis in the Tarim River Basin (North-Western China), Based on Google Earth Engine Cloud Platform. Water 2020, 12, 2822. [CrossRef]

49. Wang, C.; Jia, M.; Chen, N.; Wang, W. Long-term surface water dynamics analysis based on Landsat imagery and the Google Earth Engine platform: A case study in the middle Yangtze river basin. Remote Sens. 2018, 10, 1635. [CrossRef]

50. Deng, Y.; Jiang, W.; Tang, Z.; Ling, Z.; Wu, Z. Long-Term Changes of Open-Surface Water Bodies in the Yangtze River Basin Based on the Google Earth Engine Cloud Platform. Remote Sens. 2019, 11, 2213. [CrossRef]

51. Aksoy, E.; Özsoy, G. Investigation of multi-temporal land use/cover and shoreline changes of the Uluabat Lake Ramsar Site using RS and GIS. In Proceedings of the International Conference on Sustainable Land Use and Management, Canakkale, Turkey, 13 October 2002; pp. 73-79.

52. Reis, S.; Yilmaz, H.M. Temporal monitoring of water level changes in Seyfe Lake using remote sensing. Hydrol. Process. An Int. J. 2008, 22, 4448-4454. [CrossRef]

53. Dadaser-Celik, F.; Bauer, M.E.; Brezonik, P.L.; Stefan, H.G. Changes in the Sultan Marshes ecosystem (Turkey) in satellite images 1980-2003. Wetlands 2008, 28, 852-865. [CrossRef]

54. Sertel, E.; Findik, N.; Kaya, S.; Seker, D.Z.; Samsunlu, A. Assessment of landscape changes in the Kizilirmak Delta, Turkey, using remotely sensed data and GIS. Environ. Eng. Sci. 2008, 25, 353-362. [CrossRef]

55. Dirim, M.S.; Aksoy, E.; Özsoy, G. Remote Sensing and Gis Applications for Monitoring Multi-temporal Changes of Natural Resources in Bursa-Turkey. J. Biol. Environ. Sci. 2009, 3, 53-59. 
56. Yildırım, U.; Uysal, M. Changes in the Coastline of the Burdur Lake between 1975 and 2010. In Proceedings of the International Symposium on Environmental Protection and Planning: Geographic Information Systems (GIS) and Remote Sensing (RS) Applications (ISEPP), Izmir, Turkey, 28-29 June 2011; pp. 28-29.

57. Kuleli, T.; Guneroglu, A.; Karsli, F.; Dihkan, M. Automatic detection of shoreline change on coastal Ramsar wetlands of Turkey. Ocean. Eng. 2011, 38, 1141-1149. [CrossRef]

58. Bolca, M.; Özen, F.; Güneş, A. Land use changes in Gediz Delta (Turkey) and their negative impacts on wetland habitats. J. Coast. Res. 2014, 30, 756-764.

59. Ozturk, D.; Beyazit, I.; Kilic, F. Spatiotemporal analysis of shoreline changes of the Kizilirmak Delta. J. Coast. Res. 2015, 31, 1389-1402. [CrossRef]

60. Durmaz, F.; Karakaya, N.; Evrendilek, F. Spatiotemporal change detection analysis of Turkish lake water surface area in response to anthropogenic ecosystem disturbances using Long-Term Landsat TM/ETM+ Data. J. Ecosys. Ecograph 2016, 6, 2.

61. Temiz, F.; Bozdag, A.; Durduran, S.S.; \& Gumus, M.G. Monitoring coastline change using remote sensing and GIS technology: A case study of Burdur Lake, Turkey. Fresenius Environ. Bull. 2017, 26, 7235-7242. [CrossRef]

62. Sarp, G.; Ozcelik, M. Water body extraction and change detection using time series: A case study of Lake Burdur, Turkey. J. Taibah Univ. Sci. 2017, 11, 381-391. [CrossRef]

63. Kaplan, G.; Avdan, Z.Y.; Avdan, U. Mapping and monitoring wetland dynamics using thermal, optical, and SAR remote sensing data. In Book Wetland Manegemet-Asssessing Risk and Sustainable Solutions; Intech Open: London, UK, 2019. [CrossRef]

64. Ciritci, D.; Türk, T. Automatic detection of shoreline change by geographical information system (GIS) and remote sensing in the Göksu Delta, Turkey. J. Indian Soc. Remote Sens. 2019, 47, 233-243. [CrossRef]

65. Ataol, M.; Kale, M.M.; Tekkanat, İ.S. Assessment of the changes in shoreline using digital shoreline analysis system: A case study of Kizılırmak Delta in northern Turkey from 1951 to 2017. Environ. Earth Sci. 2019, 78, 579. [CrossRef]

66. Yagmur, N.; Musaoglu, N. Temporal Analysis of Ramsar Sites via Remote Sensing Techniques-A Case Study of Meke Maar. In IOP Conference Series: Materials Science and Engineering, Proceedings of the 4th International Conference on Buildings, Construction and Environmental Engineering, Istanbul, Turkey, 7-9 October 2019; IOP Publishing: Bristol, UK, 2020; Volume 737, p. 012248. [CrossRef]

67. Sabuncu, A. Burdur Gölü Kıyı Şeridindeki Değişiminin Uzaktan Algılama ile Haritalanması. Afyon Kocatepe Üniv. Fen Ve Mühendislik Bilimleri Derg. 2020, 20, 623-633.

68. Hepdeniz, K. Determination of Burdur Lake's areal change in upcoming years using geographic information systems and the artificial neural network method. Arab. J. Geosci. 2020, 13, 1143. [CrossRef]

69. Tercan, E.; Atasever, U.H. Effectiveness of autoencoder for lake area extraction from high-resolution RGB imagery: An experimental study. Environ. Sci. Pollut. Res. 2021, 24, 31084-31096. [CrossRef]

70. Dervisoglu, A.; Bilgilioglu, B.B.; Yagmur, N.; Musaoglu, N.; Tanik, A. Temporal assessment of natural wetlands via remotely sensed data: A case study from Turkey. FEB-Fresenius Environ. Bull. 2019, 28, 1005.

71. Nasa.gov. Available online: https://landsat.gsfc.nasa.gov/landsat-4-5 (accessed on 10 April 2021).

72. Nasa.gov. Available online: https://landsat.gsfc.nasa.gov/landsat-8 (accessed on 10 April 2021).

73. Temperature and Precipitation Assessment in River Basins According to Climate Projections, Turkish State Meteorological Service; Report; Ankara, Turkey, 2014. (In Turkish)

74. Feyisa, G.L.; Meilby, H.; Fensholt, R.; Proud, S.R. Automated Water Extraction Index: A new technique for surface water mapping using Landsat imagery. Remote Sens. Environ. 2014, 140, 23-35. [CrossRef]

75. McFeeters, S.K. The use of the Normalized Difference Water Index (NDWI) in the delineation of open water features. Int. J. Remote Sens. 1996, 17, 1425-1432. [CrossRef]

76. Rokni, K.; Ahmad, A.; Selamat, A.; Hazini, S. Water feature extraction and change detection using multitemporal Landsat imagery. Remote Sens. 2014, 6, 4173-4189. [CrossRef]

77. Zhou, Y.; Dong, J.; Xiao, X.; Xiao, T.; Yang, Z.; Zhao, G.; Zou, Z.; Qin, Y. Open surface water mapping algorithms: A comparison of water-related spectral indices. Water 2017, 9, 256. [CrossRef]

78. Acharya, T.D.; Subedi, A.; Lee, D.H. Evaluation of water indices for surface water extraction in a Landsat 8 scene of Nepal. Sensors 2018, 18, 2580. [CrossRef]

79. Zhang, J.; Ding, J.; Wu, P.; Tan, J.; Huang, S.; Teng, D.; Cao, X.; Wang, J.; Chen, W. Assessing arid Inland Lake Watershed Area and Vegetation Response to Multiple Temporal Scales of Drought Across the Ebinur Lake Watershed. Sci. Rep. 2020, 10, 1354. [CrossRef]

80. Turkiyesulakalanlari.com. Available online: http://www.turkiyesulakalanlari.com/meke-maari-konya/ (accessed on 1 April 2021).

81. Milliyet.com.tr. Available online: https://www.milliyet.com.tr/tatil/meke-golu-konya-ilinde-nerede-golun-ozellikleri-olusumuve-tarihcesi-6314044 (accessed on 5 April 2021).

82. Ensonhaber.com. Available online: https://www.ensonhaber.com/ic-haber/seyfe-golu-kuraklikla-mucadele-ediyor (accessed on 5 April 2021).

83. Sozcu.com.tr. Available online: https://www.sozcu.com.tr/hayatim/seyahat/burdur-golunun-son-konuklari-flamingolar/ (accessed on 5 April 2021).

84. Iha.com.tr. Available online: https:/ / www.lha.com.tr/dogu-anadolunun-kus-cenneti-kuyucuk-golu-3399h.htm (accessed on 5 April 2021). 
85. Aa.com.tr. Available online: https://www.aa.com.tr/tr/turkiye/kars-baraji-tarima-can-suyu-olacak/1256621 (accessed on 5 April 2021).

86. Odatv4.com. Available online: https:/ / odatv4.com/beton-skandalina-sorusturma-16082043.html (accessed on 6 April 2021).

87. Turkiyesulakalanlari.com. Available online: http://www.turkiyesulakalanlari.com/nemrut-krater-golu-bitlis/ (accessed on 5 April 2021).

88. Atlasdergisi.com. Available online: https://www.atlasdergisi.com/kesfet/doga-cografya-haberleri/cennetin-kanatlari.html (accessed on 6 May 2021).

89. Turkiyesulakalanlari.com. Available online: http://www.turkiyesulakalanlari.com/ulubat-golu-bursa/ (accessed on 6 May 2021).

90. Ferdaaydar.com. Available online: http://www.ferdaaydar.com/turkiye-seyahat-rehberi/bursanin-sirin-beldeleri-golyazi-veuluabat-golu-apollont/ (accessed on 6 May 2021).

91. Facebook.com. Available online: https://www.facebook.com/trtavaz/photos/pcb.717109958357208/717109295023941/ (accessed on 6 May 2021).

92. Neredenegezilir.com. Available online: http://neredenegezilir.blogspot.com/2014/12/kzoren-obrugu.html (accessed on 5 June 2021).

93. Ensonhaber.com. Available online: https://www.ensonhaber.com/yasam/konyada-obruk-golundeki-su-28-metre-azaldi (accessed on 6 June 2021). 